\title{
Çoğulculuk ve Vesayet İkileminde 1961 Anayasası*
}

\section{The Constitution of 1961 in the Dillemma of Pluralism and Tutelage}

\author{
Dr. Mürşide ŞİMŞEK (iD) 1
}

\begin{abstract}
$\ddot{O} z$
Doktrinde 1961 Anayasası'nın geniş ölçüde yer verdiği temel hak ve hürriyetlerle çoğulcu demokrasiyi getirdiği iddiası yaygın olarak kabul görmektedir. Bu yaklaşımı benimseyenler 1961 Anayasası'nın hazırlık sürecinde ve uygulanmasında temel hak ve hürriyetlerin toplumun tüm kesimleri için tanınmasının esas kabul edildiğini ileri sürerler. Neticede 1961 Anayasası'nın siyasal yelpazenin genişlemesinin önünü açtığı ifade ederler. Söz konusu iddianın gerçek olmadığını kabul eden yaklaşım 1961 Anayasası'nda çoğulcu demokrasinin hayat bulmasını engelleyecek kurumsal düzenlemelere yer verildiğini ve böylece demokrasiyi budayacak vesayet tohumlarının ekildiğini ileri sürmektedir. Bu yaklaşıma göre 1961 Anayasası ile tanınan temel hak ve hürriyetlerin toplumun tüm kesimlerince kullanılması başta Anayasa Mahkemesi olmak üzere çeşitli kurumsal araçlarla dolaylı olarak engellenmiştir. Makalede bu iki iddia ele alınmış ve 1961 Anayasası'nın tanıdığı özgürlüklerin uygulamada hangi kesimlerce kullanılabildiği ve bu özgürlüklerin kullanılmalarının kurumsal düzeyde engellenip engellenmediği araştırılmıştır. Bu kapsamda öncelikle 1961 Anayasası'nın hazırlık sürecinde etkili olan yaklaşım ve bu yaklaşımın temel amaçlarına bakılmıştır. Daha sonra 1961 Anayasası'nda yer verilen ve resmi ideolojinin taşıyıcilığ misyonu yüklendiği iddia edilen Anayasa Mahkemesi (AYM), Milli Güvenlik Kurulu (MGK), Cumhuriyet Senatosu, Cumhurbaşkanlığı, Devlet Planlama Teşkilatı (DPT) yetkileri, görevleri ve siyasal arenada vesayetçi işlev yerine getirip getirmedikleri açısından incelenmiştir. Neticede 1961 Anayasası'nın felsefesine ve uygulamadaki duruma bakılarak Anayasayla ilgili çoğulculuk - vesayet ikilemi tartı̧̧masına katkıda bulunulmuştur.
\end{abstract}

Anahtar Kelimeler: 1961 Anayasası, resmi ideoloji, vesayet, çoğulcu demokrasi, temel hak ve hürriyetler

Makale Türü: Araştırma

\begin{abstract}
In the doctrine, the claim that the 1961 Constitution introduced pluralist democracy with fundamental rights and freedoms, is widely accepted. Those who adopt this approach claim that the recognition of fundamental rights and freedoms for all segments of the society is essentially considered in the preparation and implementation of the 1961 Constitution. As a result, they express that the 1961 Constitution paved the way for the expansion of the political spectrum. The approach, which accepts aforesaid claim untrue, asserts that the 1961 Constitution includes institutional arrangements that will prevent pluralist democracy come to life, and thus the seeds of tutelage that will prune democracy are planted. According to this approach, the use of fundamental rights and freedoms recognized by the 1961 Constitution by all segments of society was prevented indirectly by various institutional means, particularly the Constitutional Court. In the article, these two allegations were discussed and it was investigated that the freedoms granted by the 1961 Constitution could be used in practice by which groups and whether the use of these freedoms was prevented at the institutional level. In this context, at the outset, the effective approach in the preparation process of the 1961 Constitution and the main objectives of this approach were examined. Later, the Constitutional Court (AYM), National Security
\end{abstract}

\footnotetext{
* Bu makale İdeolojik Aygıt Olarak Türkiye'de Anayasalar (1982 Dönemi Öncesi) isimli doktora tezinden türetilmiştir.

${ }^{1}$ Afyon Kocatepe Üniversitesi, İktisadi ve İdari Bilimler Fakültesi, mursidekorkut@ hotmail.com.
}

Atıf için (to cite): Şimşek, M. (2020). Çoğulculuk ve vesayet ikileminde 1961 Anayasası. Afyon Kocatepe Üniversitesi Sosyal Bilimler Dergisi, 22(TBMM'nin 100. Yılı ve Millî İrade Özel Sayısı), 221-240. 
Council (MGK), the Republic Senate, Presidency, State Planning Organization (DPT), which were included in the 1961 Constitution and claimed to undertake the mission of carrying the official ideology, were examined in terms of their authorities, duties and whether they fulfil a tutelaged function in the political arena. Consequently, weeding through the philosophy of the 1961 Constitution and the situation in practice, a contribution is made to the discussion of constitutional pluralism - tutelage dilemma.

Keywords: 1961 Constitution, official ideology, tutelage, plural democracy, fundamental rights and freedoms

Paper Type: Research

\section{Giriş}

Siyasal ve hukuki sistemin kurucu normu olmaları itibariyle anayasalar demokratik sistemin yapısal özelliklerini ve işleyişini büyük ölçüde belirleme gücüne sahip olurlar. Yürürlükte kaldığı müddetçe anayasalar kendilerini kuran iktidarlar tarafindan tasarlanan siyasi düzen ve hukuki felsefe ile toplumların şekillenmesinde etkili olurlar. Türk anayasalarında da demokratik sistemin çoğulcu/çoğunlukçu yapısı anayasada kurulmuş olan siyasal yapıya, tanınan temel hak ve özgürlüklere ve bu hak ve özgürlüklerin sınırlanmasına bağlı olarak şekillenmiştir. 1924 Anayasası açık şekilde çoğunlukçu demokrasi anlayışına uygun bir sistem kurgulamıştır. 1961 Anayasası ile gelen sistemin çoğulcu demokrasiye mi yoksa vesayetçi anlayışa mı uygun bir sistem olduğu ise tartışmalıdır. Makalenin temel sorununu bu tartışma oluşturmaktadır. Makalede bu tartışmaya katkıda bulunmak için öncelikle 1961 Anayasası'nın hazırlanış sürecinde Anayasaya yüklenmek istenen felsefi arka plan ele alınacaktır. Daha sonra Anayasa'da yer verilen kurumlardan Cumhurbaşkanlığı, Milli Güvenlik Kurulu, Anayasa Mahkemesi, Cumhuriyet Senatosu ve Devlet Planlama Teşkilatı ele alınacak ve sivil siyaset üzerindeki etkilerinin vesayetçi mi çoğulcu mu olduğu tespit edilecektir.

\section{Yöntem}

Bu çalışma dönemsel bir araştırma makalesidir. 1960 - 1980 arası dönemde Türkiye'de yaşanan siyasal ve hukuki gelişmeler analiz edilmiş ve 1961 Anayasası'nın kurduğu siyasal sistemin niteliği tespit edilmeye çalışı1mıştır. Çalışma literatür taraması yöntemi ile yapılmış olup, konuya ilişkin makale, dergi, kitap, Temsilciler Meclisi Tutanakları ve Anayasa Mahkemesi Kararlarından faydalanılmıştır. Türkiye Cumhuriyeti Devleti'nin 1961- 1980 arası döneminde yürürlükte olan 1961 Anayasası'nın hazırlık sürecinin nasıl şekillendiği ve bu süreçte Anayasa ile siyasal sisteme eklenen yeni kurumlara kurucu iktidarın yüklediği misyon araştırılmıştır. Bu kurumların işlem ve kararlarının siyasal yapı üzerindeki etkileri incelenmiştir. Neticede kurucu iktidarın kendilerine yükledikleri misyon çerçevesinde bu kurumların bazılarının demokratik sistemin vesayet denetimi altında tutulmasına sebep oldukları anlaşılmıştır.

\section{1961 Anayasası'nın Kurucu İktidarı}

27 Mayıs Darbesi'ni yapan Milli Birlik Komitesi, askeri iktidarı sivil iktidara devretmek için İstanbul Üniversitesi hocalarına (Onar Komisyonu) bir anayasa hazırlamaları talimatı vermiştir ${ }^{2}$. Onar Komisyonu da Ankara Üniversitesi Siyasal Bilgiler Fakültesi İdari İlimler Enstitüsü'nden (Ankara Komisyonu'ndan) görüş bildirmesini istemiş̧ir. Ankara Komisyonu görüş talebine, başlı başına bir anayasa tasarısı hazırlayarak yanıt vermiş ayrıca yeni bir anayasa yapımı için seçimle bir Kurucu Meclis oluşturulması gerektiğini ve böylece hazırlanacak belgenin kamuoyu tarafından tartışılmasının doğru olacağını belirtmiştir (Özutku, 2016, s. 6). Onar Komisyonu'nun hazırladığı tasarı kamuoyunda ve Milli Birlik Komitesi (MBK) içinde

\footnotetext{
${ }^{2}$ Onar Komisyonu olarak da adlandırılan bilim kurulunda yer alan İstanbul Üniversitesi Hukuk Fakültesi öğretim üyeleri Sıddık Sami Onar, Hıfzı Veldet Velidedeoğlu, Hüseyin Nail Kubalı, Tarık Zafer Tunaya, Ragıp Sarıca ve İsmet Giritli’dir (Akın, 2010, s.113).
} 
ciddi eleştirilere maruz kalınca Anayasanın özel olarak oluşturulan bir kurucu meclise hazırlatılmasına karar verilmiştir (Özbudun, 2016, s. 36). Anayasa hazırlanması konusu MBK içindeki bölünmenin önemli sebeplerinden biri olmuştur. Geçici Anayasa gereği bir Kurucu Meclis oluşturulması için MBK içinde 4/5 çoğunluğun Kurucu Meclis oluşturmayı kabul etmesi gerekmektedir. Yeterli çoğunluk sağlanamadığından yetkilerini Kurucu Meclis'e devretmeyi istemeyen MBK içindeki 14 kişi tasfiye edilmiştir (İpekçi ve Coşar, 2010, s.396 - 413). Böylece Anayasa hazırlaması için MBK tarafından 157 sayılı Kurucu Meclis Teşkili Hakkında Kanun çıkarılmıştır (RG, Gün: 16 Aralık 1960, Sayı: 10682).

Kurucu Meclis Teşkili Hakkında Kanun kapsamında toplanan ve 1961 Anayasası'nı hazırlayan Kurucu Meclis iki kanatlıdır. Kurucu Meclis'in birinci kanadı, askeri kanat olarak da nitelenen MBK'dır. MBK'nın 14 üyesi 13 Kasım 1960'da tasfiye edilmiş, bir üyesi de istifa etmiş bu nedenle toplam 23 üyesi kalmıştır. Kurucu Meclis'in ikinci kanadı, sivil kanat olarak da nitelenen Temsilciler Meclisi'dir. Temsilciler Meclisi'nin oluşumu 158 sayılı Temsilciler Meclisi Seçimi Kanunu'nda düzenlenmiștir. İlgili kanunun 2. maddesine göre Temsilciler Meclisi'ne 10 üye Devlet Başkanı tarafından, 18 üye MBK üyeleri, 75 üye illerin temsilcileri, 49 üye CHP, 25 üye CKMP, 6 üye barolar, 12 üye basın, 2 üye Eski Muharipler Birliği, 6 üye esnaf kuruluşları, 1 üye gençlik, 6 üye işçi sendikaları, 10 üye odalar, 6 üye öğretmen kuruluşları, 6 üye tarım kuruluşları, 12 üye üniversitelerden, 12 üye yargı organları tarafından seçilen temsilcilerden oluşmuştur (RG, Gün: 16 Aralık 1960, Sayı: 10682).

İlgili Kanunun Seçilme Yeterliliği başlıklı 6. maddesinin son fikrasında "Faaliyetleri, yayınları ve davranışları ile 27 Mayıs İtilaline kadar anayasaya, insan haklarına aykırı icraat ve siyaseti desteklemekte devam etmiş olanlar, Temsilciler Meclisine üye seçilemezler" hükmüne yer verilerek, darbe sonrası kapatılmış olan Demokrat Parti'ye (DP) temsilci gönderme hakkı tanınmamıştır. DP'nin 1957 seçimlerinde aldığı (\%47,3 oranında) oy düşünüldüğünde (Zürcher, 2017, s. 338) Kurucu Meclis'te siyasal açıdan toplumun önemli bir kesiminin temsilinin engellendiği anlaşılmaktadır (Gözler, 2000, s. 82).

Temsilciler Meclisi'nde mesleki temsile dayanan oluşumun ağırlıklı olduğu görülmektedir. Onar Komisyonu, Kurucu Meclis'in siyasal parti temsilcilerinden değil, sadece meslek temsilcilerinden oluşmasını talep etmiş ${ }^{3}$ ancak Ankara Komisyonu'nun itirazı ile bu talep kabul görmemiştir (Karpat, 2017, s. 171 - 172). Neticede mesleki temsil yanında siyasi temsil de mümkün olmuştur.

Temsilciler Meclisi'nin oluşumuna ilişkin yapılacak seçimler genel oya dayanmadığı gibi tek dereceli de değildir. İllerin temsilcileri üç basamaklı seçim sonucu (ilçe delegeleri seçme kurulu, ilçe delegeleri ve il temsilcileri) belirlenmiştir. İl temsilcisi olarak seçilen kişilerin, toplumun orta gelir sınıfina mensup ve CHP siyasetine yakın isimler olduğu görülmüştür (Karpat, 2017, s.172). DP'ye yakın isimlerin dışarıda bırakılmasının etkisiyle Temsilciler Meclisi'nde il temsilcileri bazında da toplumun tüm kesimlerinin temsili mümkün olmamıştır.

Kurucu Meclis'in sayısal olarak çoğunluğunu Temsilciler Meclisi oluşturmuş ancak siyasal olarak daha az etkili olabilmiştir. Kurucu Meclis'te sayısal olarak azınlıkta olan MBK ise siyasal açıdan ağırlıklı olarak etkili olan kanat olmuştur ${ }^{4}$. Temsilciler Meclisi içinde ise Devletçi Grup ve Liberal Grup olmak üzere iki grup oluşmuştur. Kurucu Meclis'in siyasal ortamında askerlerin psikolojik baskısı ve Kemalist anlayışın ilkeleri tartışmasız egemen olurken sayısal olarak azınlıkta da olsa ordunun desteği ile Temsilciler Meclisi'nde aktif olan ve taleplerini kabul ettiren grup Devletçi Grup olmuştur. Liberal Grupsa kendisini Devletçi Grup

\footnotetext{
${ }^{3}$ Onar Komisyonunun önerdiği model korporatist modeldir. Korporatist modelde siyasal oluşumlar değil dayanışmacı sosyal aktörler olan ve mal ve hizmetleri üreten mesleklerin temsili esastır (Aydın ve Taşkın, 2018, s.82).

${ }^{4}$ Kurucu Meclis toplantı salonunda ön taraf MBK üyelerine ayrılmışken, arkalarındaki kısım Temsilciler Meclisine ayrılmıştır. Temsilciler Meclisi üyelerine ayrılan kısmın arkası da dinleyicilere ve basına ayrılmıştır. Bu durum toplantı salonunda psikolojik bir hiyerarşi oluşturmuştur. (Toplu, 1976, s. 69.)
} 
kadar ifade edememiştir ${ }^{5}$. Bu nedenle de 1961 Anayasası taslağı için toplumsal uzlaşıya dayalı olarak, demokratik yollarla oluşturulmuştur denemez (Tanör, 2017, s. 370).

Temsilciler Meclisi'ndeki siyasal ortam, Meclis üyelerinden Abdülhadi Toplu'nun hatıralarına şöyle yansımıştır: "Temsilciler Meclisi, Milliyetçiler Derneğinden tanıdığım üç beş CKMP'li olmasa adeta CHP'nin küçük kurultayını andırıyor. CHP Kontenjanından bütün parti meclisi üyeleri genel başkanlart ile birlikte meclise gelmişlerdi. Kurucu Meclis olarak görülen manzara ise, bir askeri cuntanın istişari meclisi niteliğinde idi...” (Toplu, 1976, s. 73). Toplu'nun da belirttiği üzere Temsilciler Meclisi'nin en belirgin iki özelliğinden ilki, üyelerinin çoğunluğunun CHP'ye yakın dünya görüşünden kişiler olmasıdır. İkincisi ise üyelerin üzerinde, darbe ile iktidara el koymuş MBK'nin baskısının açıkça hissediliyor olmasıdır'. CHP'nin İlk Hedefler Beyannamesi adıyla açıkladığı ve iktidara geldiğinde gerçekleştirmeyi vaad ettiği Anayasal reformların (iki meclisli parlamento,nıspi temsil, Anayasa Mahkemesi, ekonomik planlama gibi reformların) Darbe sonrasında hazırlanan Anayasada yer alması da Anayasa hazırlık sürecinde CHP'nin etkin olduğunu göstermektedir (Ahmad, 1992, s.145, 292).

1961 Anayasası metni hazırlanırken Temsilciler Meclisi içinde bir Anayasa Komisyonu oluşturulmuştur. Komisyon önce Türkiye'deki Anayasa hareketlerinin seyrini anlatan bir rapor hazırlamıştır. Bu raporda 1924 Anayasası'nın kuvvetler birliği esasına ve Meclis üstünlüğü ilkesine dayanan çoğunlukçu demokrasi anlayışının, kamuoyunu dışarda tuttuğu iddia edilmiştir. Tüm yetkinin yasamada olduğu bu sistemin 1946 sonrasındaki seçim sistemi ile uyumsuz olduğu ileri sürülmüştür (Karpat, 2017, s. 176). Ayrıca 27 Mayıs Darbesi için toplumu dikta yönetimi altına almaya çalışan bir partiden kurtarmak amacına yönelik, direnme hakkının kullanıldığ ' 'haklı bir halk hareketi' ifadesi kullanılmıştır (Akgün, 1981, s. 70 - 99; Göze, 1970, s. 42). Anayasa Komisyonundaki 27 Mayıs Darbesini bir ihtilal hatta bir inkılap olarak gören yaklaşım, 1961 Anayasası Başlangıç kısmına da yansımıştır. 1961 Anayasası Başlangıç kısmında "27 Mayıs 1960 Devrimini yapan Türk Milleti” ifadesine yer verilmiş ve 27 Mayıs Darbesi adeta bir halk devrimi gibi yansıtılmaya çalışılmıştır.

Temsilciler Meclisi içinde oluşturulan Anayasa Komisyonu, İstanbul Üniversitesi hocaları tarafından hazırlanan Onar tasarısını etüt metni, Başkanlığını Prof. Dr. Tahsin Bekir Balta'nın yaptığı Ankara Üniversitesi Siyasal Bilgiler Fakültesi hocalarının ${ }^{7}$ hazırladığ Ankara tasarısını yardımcı metin olarak kullanmıştır (Gözler, 2019, s. 105). 1960 döneminde İstanbul Üniversitesi Hukuk Fakültesi hocalarının çalışmaları daha çok 19. yüzyıl Avrupalı hukukçuların teorileri üzerine yoğunlaşmışken, Ankara Üniversitesi Siyasal Bilgiler Fakültesi hocalarının çalışmaları modern siyaset bilimi kavramlarını merkeze alan çalışmalar olmuştur. Bu durumun etkisi ile İstanbul Üniversitesi hocalarının aksine Ankara Üniversitesi hocaları siyasal partileri sosyal hareketliliğin ve siyasal eğilimin önemli araçları olarak değerlendirmişlerdir (Karpat, 2017, s.171 - 172; Tanör, 2017, s.382). İstanbul tasarısından farklı olarak Ankara tasarısında siyasi partilere, genel oya ve yürütmeye aşırı kuşkucu bir yaklaşım yoktur. Her iki tasarıdaki ortak hususlarsa: çoğunluk egemenliğine karşı, anayasa ile düzenlenmiş bir demokrasi anlayışı ve laikliğin pekiştirilmesi olmuştur (Tanör, 2017, s. 372). Ayrıca Kurucu Meclis 1946 Fransız Anayasası'ndan, 1947 İtalyan Anayasası'ndan, 1949 Federal Alman Anayasası'ndan yararlanmıştır (Dal, 1986, s.56; Arsel, 1965, s.138). Anayasa Komisyonu'ndan çıkan anayasa

${ }^{5}$ Devletçi Grup: Merkezden radikal sola kadar uzanan çizgideki kesimin temsilcilerinden oluşuyordu ve ordu tarafindan destekleniyordu. Liberal Grup: Merkezden radikal sağa kadar uzanan kesimin temsilcilerinden oluşuyordu ve tarımsal, ticari ve mahalli çıkar çevrelerince destekleniyordu. (Karpat, 2017, s. 173).

${ }^{6}$ CHP'li olmayanları MBK üyeleri 'Bu sefer Yassıada'yı da göremeden gidersiniz' ifadeleri ile tehdit edilmiştir (Erim, 2005, s. $741)$.

${ }^{7}$ Ankara Komisyonu Tasarısı hazırlanmadan önce Ankara İdari İlimler Enstitüsü tarafından öncelikle yeni Anayasanın yapılış tarzı meselesi tartışılmıştır. Bu tartışmaya Prof. Dr. Tahsin Bekir Balta, Prof. Dr. Yavuz Abadan, Prof. Dr. Bahri Savcı, Dr. Necat Erder ve Dr. Bülent Daver katılmıștır. Bu tartışmadan da beslenen Ankara Tasarısı hazırlık sürecine ise Dr. Tahsin Bekir Balta, Prof. Dr. Yavuz Abadan, Prof. Dr. Süheyp Derbil, Kemal Balkar, Doç. Dr. Arif T. Payaslıoğlu, Doç. Dr. Cemal Mihçıoğlu, Doç. Dr. İbrahim Yasa, Dr. Bülent Daver, Dr. Şeref Gözübüyük, Dr. Necat Erder, Dr. Türkkaya Ataöv, Dr. Cemal Aygen, Taner Timur, Özer Ozankaya katılmıştır. Yazım aşamasında Prof. Dr. Tahsin Bekir Balta, Dr. Necat Erder, Dr. Bülent Daver, Dr. Türkkaya Ataöv, Doç Dr. İlhan Unat, A. Gündüz Ökçün katılmıştır (Siyasal Bilgiler Fakültesi İdari İlimler Enstitüsü’nün Anayasa Tasarısı, 1960, Önsöz'den). 
taslak metni Temsilciler Meclisi'nde (Anayasa Komisyonu üyelerinin de katıldıkları toplantılarda) tartışılmıştır.

Temsilciler Meclisi'nde kabul edilen metin MBK'ya gönderilmiştir. MBK ilgili metinde bir kısım değişiklikler yapılmasını istemiştir. Değişiklik talebi tekrar Temsilciler Meclisi’nde görüşülmüştür. Uygun görülen değişiklikler yapılmış uygun görülmeyen değişiklikler için eski metinde 1 srar edilmiştir. MBK ve Temsilciler Meclisi'nin uzlaşamadığı maddeler için her iki kurulun katıldığı Karma Komisyon toplanmış ve bu komisyon kararından çıkan metinle referanduma giden 1961 Anayasası taslağı hazırlanmıştır ${ }^{8}$.

\section{1961 Anayasası'nın Felsefi Arka Planı}

1961 Anayasası'ndaki ideolojik tercihleri toplum değil, darbe ile demokratik iktidardan siyasi gücü devralan kesim, Tanör'ün ifadesiyle "Zinde Kuvvetler" belirlemiştir (Tanör, 2017, s.370). Darbenin arkasındaki güç (zinde kuvvetler) ise DP'nin halk desteği ile tekrar tekrar iktidara gelmesi sonucu prestij kaybına uğrayan sivil ve askeri bürokrasiden oluşmuştur'. Bu gücün kontrolündeki kurucu iktidarın anayasa hazırlarken temel aldığı amaç DP benzeri bir partinin tekrar iktidara gelip devlet erklerinin tamamı üzerinde tek başına güç sahibi olmasını önlemek olmuştur. Bu bakımdan 1961 Anayasası'nın asli özelliklerinden biri tepki anayasası olarak hazırlanmasıdır (Karatepe, 2009, s. 215).

1961 Anayasası 1924 Anayasası'na ve DP iktidarına tepki niteliğinde hazırlanmıştır. Gerek Forum dergisinde gerekse İlk Hedefler Bildirgesi'nde yer verilen eleştirlerden ve DP döneminde tartışılan siyasal konulardan hareketle görülmektedir ki DP iktidarı döneminde hangi konularda CHP muhalefet üretti ise 1961 Anayasası'nda bu konulara özel düzenlemeler yapılmıştır. CHP, DP'yi irticanın önünü açmakla suçlamıştır. 1961 Anayasası'nda ibadet dini ayin ve tören özgürlüğünün "kamu düzenine veya genel ahlaka aykırı olmamak" şeklindeki geniş yorumlanmaya müsait özel bir sınırlandırma sebebi ile birlikte düzenlenmiştir ${ }^{10}$. CHP, DP'yi ekonomiyi yönetememekle suçlamıştır. 1961 Anayasası'nda ekonomi politikalarını yönlendirmesi için DPT kurulmuştur. CHP, DP'yi Anayasayı ihlal etmekle suçlamıştır. 1961 Anayasası ile kanunların ve TBMM İçtüzüğünün Anayasaya uygunluğunu denetlemesi için Anayasa Mahkemesi kurulmuştur. CHP, DP'yi Atatürk'ün devrimlerine sahip çıkmamakla eleştirmiştir. 1961 Anayasası'nın başlangıç kısmında “Atatürk Devrimlerinin tam şuuruna sahip olarak" ifadesine yer verilmiş ve 2. maddesine "Başlangıç'ta belirtilen temel ilkelere dayanan ... hukuk devleti" ifadesi eklenmiştir (Çakmak, 2007, ss. 261- 271; Kaçmazoğlu, 2012, ss. 106 - 107; Tuğluoğlu, 2017, ss. 297 - 298).

1961 Anayasası sosyal hakları da kapsamas ${ }^{11}$ ve temel hak ve özgürlükleri koruyucu hükümleri' ${ }^{12}$ ile ilk bakışta çoğulcu demokrasi getirmeye yönelik hazırlandığı izlenimi vermektedir. Uygulamada 1961 Anayasası'nda tanınan temel hak ve özgürlüklerin, zinde

\footnotetext{
81961 Anayasası metninin hazırlık süreci 157 sayılı Kurucu Meclis Teşkili Hakkında Kanun’un 18, 25 - 31. maddeleri uyarınca yürütülmüştür.

927 Mayıs Darbesini yapanların, Mustafa Kemal'in mirasına sahip çıkmak için yönetime el koydukları düşüncesi ile hareket ettikleri; demokrasinin başka türlü yaşatılamayacağına inandıkları ve Mustafa Kemal'in bıraktığı yerden daha ileri gitmek, tutucu ve gerici güçleri etkisiz hale getirmek ve daha halkçı bir idare kurmayı hedefledikleri ileri sürülmüştür. Ancak yaptıkları darbe ülke geleceği için toplumsal bölünmeyi körükleyerek ilerleme ve gelişmelere ayrılması gereken enerjilerin bölünmelere harcanmasına neden olmuştur. Ayrıca Türkiye siyasal tarihinde, siyasal krizleri sivil çözümlerle aşmak yerine, Kemalist ideolojilerin meşrulaştırıcı etkisinden yararlanarak darbelerle demokrasiyi kesintiye uğratmanın olağan görülmesine neden olmuştur (Yasemin, 2017, s. 114 $115)$.

${ }^{10} 1961$ Anayasası madde 19: "Herkes, vicdan ve dini inanç ve kanaat hürriyetine sahiptir.

Kamu düzenine veya genel ahlaka veya bu amaçlarla çıkarllan kanunlara aykırl olmayan ibadetler, dini ayin ve törenler serbesttir."

111961 Anayasası Üçüncü Bölüm: Sosyal ve İktisadi Haklar ve Ödevler madde 35 - 53.

121961 Anayasası 1971 değişikliklerinden önce temel hak ve hürriyetler konusunda oldukça korumalı hükümler düzenlemiştir. Ancak 1971 yılında yapılan Anayasa değişikliği ile pek çok temel hak ve özgürlüğe özel sınırlandırma sebepleri getirilmiş yahut öngörülen sınırlandırma sebepleri genişletilmiştir (Örneğin madde 15: Özel Hayatın Gizliliği, madde 19: Vicdan ve Din Hürriyeti, madde 22: Basın hürriyeti vb.). 1971 yılında 11 maddede yapılan değişiklikle temel hak ve özgürlüklere ilişsin genel sınırlandırma nedenleri Anayasaya eklenmiştir.
} 
güçlerin dünya görüşünü benimseyen kesimlere tanınırken, tüm insanlar için tanınmadığı görülmüştür ${ }^{13}$. 27 Mayıs Darbesini toplumsal eleştirilerden korumak için Tedbirler Kanunu olarak bilinen Anayasa Nizamını Milli Güvenlik ve Huzuru Bozan Bazı Fiiller Hakkındaki Kanun çıkarılmış ve DP hakkında olumlu düşünceleri ifade etmek ve 27 Mayıs Darbesini ve Yüksek Adalet Divanı kararlarını eleştirmek suç haline getirilmiştir (Tuluoğlu, 2019, s. 10 16). AYM'nin verdiği bir kararda 27 Mayıs Darbesini (mahkeme devrim ifadesini kullanmıştır) zedeleyecek nitelikte röportaj yapıp beyanat verenler hakkındaki cezalandırıcı hükmün iptali talebi Anayasa'nın "düşünce, kanaat ve basın hürriyetlerinin özüne dokunacak nitelik

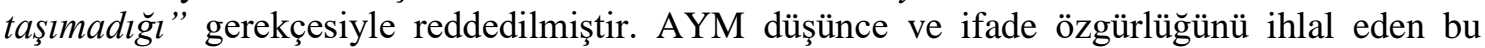
hükmün, "toplum hayatın zarardan korumaya ve güvenliği săglamaya yönelik" olduğunu kabul etmiştir (AYM, 08.04.1963 günlü karar, RG, Sayı: 11456, gün 17 Temmuz 1963). Böylece düşünce ve kanaat özgürlüğü darbeyi desteklemeyen kesim için anlamsız hale gelmiştir.

Resmi ideoloji olarak nitelendirilen Kemalizm (İnsel, 2001, s. 19) 1924 Anayasası'na 1937 yılında yapılan değişikliklerle (CHP'nin altı ilkesinin Anayasa'ya eklenmesi ile (Karatepe, 2018, s. 52)) eklenmiştir. 1961 Anayasası'nda, 1924 Anayasası'ndan farklı olarak Kemalizm Anayasanın hazırlandığı andan itibaren Anayasada yer almış ve daha çok vurgulanmıştır ${ }^{14}$. Bu durum 1961 Anayasası'nın temel felsefesinin, Atatürk Devrimleri sınırları içinde temel hak ve hürriyetlerin teminat altına alınması (Aldıkaçtı, 1964, s.19) olarak kabul edilmesinden kaynaklanmıştır. Diğer bir ifade ile 1961 Anayasası'nın felsefesinde toplumsal yapının kendine has kültürel niteliklerinin, kendi ihtiyaç ve beklentilerinin dikkate alınacağ 1 bir demokratik sistem kurmak değil, resmi ideoloji ilkeleri ile kayitlı bir demokratik sistem kurmak hedeflenmiştir. Batı toplumlarındaki statükonun erişilmesi gereken bir hedef olarak kabul edilmesi gerektiğine dair inancın 1961 Anayasası'nda da devam ettiği anlaşılmaktadır (Köker, 2012, s. 231).

1961 Anayasası, yasama ve yargıyı yetki olarak tanımlarken ${ }^{15}$ yürütmeyi ise görev olarak tanımlamışırı ${ }^{16}$. Yürütmenin bir erk olmakla birlikte bir yetki olmaması, onun kontrol alanının daraltılması isteğinden kaynaklanmıştır. 1961 Anayasası, toplumsal çoğunluğa ve onun temsilcisi olan seçilmiş hükümetlere güvensizliğini onların yetkilerini kısıtlayacak Cumhuriyet Senatosu (m.70), AYM (m.145 - 152), MGK (m.111), DPT (m. 129) gibi yeni organlara yer vererek göstermiştir (Erdoğan, 2003, ss. 90 - 92).

\section{Vesayet Taşıyıcısı Kurumlar}

Yukarıda değinildiği üzere 1961 Anayasası ile, siyasi iktidarın etkinliği sınırlandırılmak, askeri ve sivil bürokrasinin etkinliği artırılmak istenmiştir. Bu nedenle 1961 Anayasası'nda askeri ve sivil bürokrasiyi güçlendiren, siyasal çoğunluğun temsilcilerini ise sınırlandırma yetkisi olan kurumlara yer verilmiştir. Bu kurumlar doktrinde vesayet kurumları olarak nitelendirilmektedir (Aydın ve Taşkın, 2014, s. 92; Eser ve Baltacı ve Arslan, 2012, s. 81; Karatepe, 2009, s. 217). Makalede farklı çalışmalarda ortak olarak vesayet kurumu kabul edilen Anayasa Mahkemesi, Cumhuriyet Senatosu, Devlet Planlama Teşkilatı, Milli Güvenlik Kurulu ve Cumhurbaşkanlığı ele alınmıştır.

\subsection{Milli Güvenlik Kurulu}

1924 Anayasası döneminde bulunmayan bu organ ilk kez 1961 Anayasası'nın 111. maddesindeki düzenleme ile siyasal sistemimizdeki yerini almıştır. 1961 Anayasası'na böyle bir organ getirilmesinin nedenlerinden en önemlisi bu Anayasanın 27 Mayıs Darbesi'nden sonra

\footnotetext{
${ }^{13}$ Sol görüşlüler, dindarlar ve Kürtler bu özgürlüklerden gerçek anlamda yararlandırılmayan kesimlerdir (Erdoğan 2003, s. 92).

141961 Anayasası Başlangıç kısmında Atatürk Devrimlerine bağlı bir toplum idealine yöneldiği ifade edilmiştir. Ayrıca Türk milletinin dünya milletleri ailesinin eşit haklara sahip şerefli bir üyesi olma idealine yönelmiş bir toplum olduğu ifade edilmiş ve böylece Kemalizm'in batılılaşma unsuruna yer verilmiştir.

151961 Anayasası madde 5 'Yasama Yetkisi’ başlığını taşırken madde 7 'Yargı Yetkisi’ başlığını taşımaktadır.

161961 Anayasası madde 6 'Yürütme Görevi’ başlığını taşmaktadır.
} 
demokratik sisteme dönüldüğünde askeri otoritenin sivil otorite karşısındaki güçlü konumunu devamlı kılmasını sağlamaktır (Özbudun, 2016, s. 45). Askerin doğrudan siyasi iktidara el koymasına gerek kalmadan MGK aracilığıyla sivil siyaseti denetleyip yönlendirmesi ve ordunun üst düzey yöneticilerinin milli güvenlik politikalarında etkili olması amaçlanmıştır (Eser vd., 2012, s. 88).

MGK, hem uygulamada milli güvenlik kavramının geniş yorumlanması nedeniyle ${ }^{17}$ hem de dönemin siyasi konjonktürü nedeniyle Anayasa'nın ona verdiği güçten çok daha fazla güce sahip olmuştur (Özbudun, 2016, s. 45). MGK'nın anayasal görevi istişare olmasına rağmen kuruldaki askeri üyeler zamanla sivil rejim ve kurumlar üzerinde denetim olanağı elde ederek Tanör'ün tespitiyle siyasal sistem için "zaman ayarlı patlayıcı" gibi hareket etmişlerdir (Tanör, 2017, s. 411).

Ordu 1960 - 1980 döneminde MGK sayesinde siyaset üzerinde en etkili güç olmuştur (Ahmad, 1992, s. 231). Orduyu sivil kesim karşısında daha çok güçlendiren bir başka anayasal düzenleme de 1924 Anayasası'nın Milli Savunma Bakanına karşı sorumlu tuttuğu Genel Kurmay Başkanını, 1961 Anayasası'nın Başbakana karşı sorumlu tutması olmuştur (Özbudun, 2016, s. 45). Böylece şekli anlamda en az bakanların statüsüne yerleştirilen Genel Kurmay Başkanlığı, 27 Mayıs Darbesi sonrasında fiili durumda sahip olduğu psikolojik üstünlük sayesinde siyaseten bakanlardan hatta zaman zaman başbakandan daha etkili olmuştur. Sahip olduğu gücü siyaseti restore etmekte kullanmıştır (Aydın ve Taşkın, 2014, 207). Bunun en açık örneği 12 Mart Muhtırası'dır. MGK'daki dört komutan (Genelkurmay Başkanı Orgeneral Memduh Tağmaç, Kara Kuvvetleri Komutanı Orgeneral Faruk Gürler, Hava Kuvvetleri Komutanı Orgeneral Muhsin Batur, Deniz Kuvvetleri Komutanı Oramiral Celal Eyiceoğlu) 27 Mayıs Darbesi'nin üzerinden henüz 11 yıl geçmişken sivil siyasetin gidişatının iyi olmadığ gerekçesi ile muhtıra vererek hükümeti istifaya zorlamışlardır (Aydın ve Taşkın, 2018, s. 205; Birand ve Dündar ve Çapl1, 2008, ss. 178 - 207).

12 Mart Muhtırası sonrasında askerin siyasal ağırlığını artırmaya yönelik anayasal girişimler devam etmiştir. 1961 Anayasası'nın ilk halinde MGK'yı düzenleyen 111. maddeye göre MGK'daki askeri kanat 'kuvvet temsilcileri' sıfatı ile görev yaparken 1971 yılında yapılan değişiklik sonrasında 'kuvvet komutanları' sıfatı ile görev yapar hale gelmişlerdir. Böylece Anayasada MGK'nın askeri kanadı için daha sert ve güçlü bir ifade kullanılmıştır. Ayrıca yine aynı maddedeki başka bir değişiklikle MGK'nın görevi, kararların alınmasında ve koordinasyonun sağlanmasında yardım etmek için Bakanlar Kurulu'na görüş bildirmekken, 'kararların alınmasında ... gereken temel görüşleri Bakanlar Kurulu'na tavsiye' etmek haline getirilmiştir (Kili, S. ve Gözübüyük, Ş., 2006, s. 229). Bu değişiklikle MGK'nın görevi koordinasyondan ibaretken, karara temel olacak görüşleri bildirmek diğer bir ifade ile kararın omurgasını oluşturmak haline getirilerek MGK'nın etkinliği ve sivil siyaset üzerindeki baskısı oldukça arttırılmıştır. Askeri vesayetin 27 Mayıs Darbesi sonrasında 12 Mart Muhtırası ile tekrar ve bu sefer siyasal sistem içinde etkinliğini daha da güçlü hale getirecek biçimde sivil siyaseti kuşatma gücüne eriştiği görülmüştür (TBMM Raporu, 2012, s. 303). Bu güç 1980 Darbesi sürecinin en önemli bileşenlerinden biri olmuştur.

\subsection{Anayasa Mahkemesi}

1960'larda dünyada yükselen özgürlük anlayışı Türkiye'ye de yansımış ve 1961 Anayasası'nda temel hak ve özgürlük kategorisi genişletilirken, insan haklarına dayalı bir devlet kurulması öngörülmüştür ${ }^{18}$. Önemli bir hukuki denetim mekanizması olan Anayasa Mahkemesi

\footnotetext{
1727 Mayıs Darbesinden sonra askerlerin her türlü konuya müdahale etmelerini meşrulaştıran bir husus da her konun milli güvenlikle ilgili olduğu yorumunun yapılmaya başlanmış olmasıdır. 27 Mayıs Darbesi sonrasında pirinç fiyatlarından, turistik yörelere kadar her konu milli güvenlik açısından değerlendirilmesi gereken konular gibi görülmeye başlanmıştır. 27 Mayıs Darbesi sonrası dönemde milli güvenlik kavramı aşırı geniş bir kavram olarak yorumlanmıștır. (TBMM, 2012, s. 298).

${ }^{18} 1961$ Anayasası kendisinden önceki anayasalardan daha geniş ölçüde temel hak ve özgürlükleri tanımakla beraber, ekonomik ve sosyal haklar kategorisindeki temel haklara ilk kez yer veren Anayasa niteliğini taşımaktadır (Karatepe, 2009, s. 222).
} 
de (Gönenç, 2010.) 1961 Anayasası ile sisteme eklenmiş̧tir. Teorik açıdan düşünüldüğünde AYM'nin çoğulculuğu garanti altına alacak bir kurum olması beklenirken yapılan siyasal ve toplumsal analizde 1961 Anayasası döneminde AYM'nin çoğulculuğu engelleyici tutum takındığı anlaşılmaktadır.

AYM, siyasal sisteme dahil edildiği 1961 Anayasası döneminden itibaren Ergun Özbudun'un yerinde tespitiyle Ran Hirschl'in hegemonyacı koruma görüşüne uygun yapılandırılmıştır (Özbudun, 2012, s. 18). Ran Hirschl'in belirttiği üzere: hakların anayasallaşmasını sağlayan ilk grup hegemonyalarını siyasetteki değişikliklerden korumak isteyen endişeli siyasi elitlerdir ki yazar bu durumun bir ispatı olarak hakların anayasallaştığı ya da AYM'nin kurulduğu dönem parlamentosuna dikkatle bakmak gerektiğini söyler. İlgili dönemden sonra parlamentodaki üye dağılımının değiştiği/değişmeye başladığına dikkat çeker. Toplumsal talebe bağlı olarak üye dağılımı değişen parlamentodaki önceki çoğunluk, henüz tüm yetkisini kaybetmeden önce anayasal reformu tamamlama ya da AYM kurma gayretinde olmuştur ki siyasi müdahaleden ari kalacak ama kendi menfaatlerini veya dünya görüşünü koruyacak bir alan oluşturabilsin. Diğer bir ifade ile kendi dünya görüşlerini parlamentodaki yeni çoğunluğa karşı korumak için anayasa hükümleri ve AYM'yi araçsallaştırılmaktadır (Hirschl, 2004, ss. 38 - 43).

Hirschl'in örnek verdiği ülkelerdeki siyasi gücün el değiştirmesi parlamentodaki çoğunluklar arasında gerçekleşir. Bu konuda Türkiye'deki farklılık hegemonik korumayı kuran gücün parlamento dışından olmasıdır. Türkiye'de sivil siyasetten gücü zorla alan asker kesim siyasilere gücü devretmeden önce hazırladığı Anayasa ile 'koruyucu hegemonya' aracı olarak AYM'yi sisteme eklemiş böylece Türkiye' de de AYM bir hegemonik koruma işlevi üstlenmiştir (Özbudun, 2012, s. 18). Resmi ideolojiye uygun olarak devleti restore etmeyi hedefleyen darbeci güç, yasama organı karşısına, negatif kanun koyma gücüne sahip AYM'yi fren mekanizması olarak getirirken, kendi görevi olduğunu düşündüğü rejimi korumayı olağan dönemlerde AYM'ye bırakmıştır (Karpat, 2017, s. 175).

1961 Anayasası'nda kanunların Anayasaya uygunluğunun hukuki denetimini yapmas1 amaciyla düzenlenen AYM, genellikle kendisini oluşturan kesimin zihniyetine uygun şekilde rejimle ve resmi ideolojiyle uyumlu kararlar vermiştir. Güçsüz grupların eşitlik ve sosyal adalet taleplerine ilişkin davalarda özgürlükçü ve sosyal adalete yönelik kararlar vermek yerine biçimsel incelemelere özgülenmiş kararlar veren AYM, düşünce özgürlüğünü aşırı derecede sınırlandıran TCK'nin 141 ve 142. maddelerini ${ }^{19} 1961$ Anayasası'na aykırı bulmamıştır. Benzer şekilde sosyal ve ekonomik haklara ilişkin davalarda bu hakları geriletici nitelikte kararlar vermiştir (Ünsal, 1980, ss. 269 - 275).

Toplum içinde ideolojik yelpaze 1961 Anayasası'nın liberal ve sosyalist ideolojik ögelere yer vermesinin etkisiyle genişlemiş hem sağ hem sol eksenli siyasal kesimler kendilerine ülke siyasetinde yer edinmeye başlamışlardır ( Zürcher, 2017, s. 358). Ancak bu siyasal genişleme 12 Mart 1971 Muhtırası'nın getirdiği resmi ideoloji dayatmasıyla yerini denetleyici cezalandırıcı anlayışa bırakmıştır. AYM, resmi ideolojinin kalıpları dışına çıkan düşünceleri destekleyen partilerin kapatılmasına hükmetmiş̧ir. Böylece dönemsel olarak rejimle uyumlu kararlar veren AYM, vesayetçi tutumuyla siyasal alandaki daralmada önemli rol oynamıştır. AYM'nin 1961 Anayasası döneminde toplumsal farklılıkları temsil eden partileri kapatma gerekçelerinin iki resmi ideoloji unsuru merkezinde toplandığ görülür. Bu unsurlardan ilki 'milliyetçilik' ikincisi ise 'laiklik'dir.

AYM 1971 yılında Türkiye İşçi Partisi'ni (TIP'i) (AYM, E:1971/3, K:1971/3, T: 20.07.1971), 1979 yılında Türkiye Emekçi Partisi'ni (TEP'i) (AYM, E:1979/1, K:1980/1, T: 08.05.1980), 1965 tarihli 648 sayıl Siyasi Partiler Kanunu'nun 87. maddesindeki ‘ülke bütünlüğünün korunmasına' ve 89. maddesindeki 'azınlık yaratılmasının önlenmesine' ilişkin

\footnotetext{
19765 Sayılı Türk Ceza Kanunu'ndaki 141 ve 142. maddeleri ile komünizmi tehlike olarak kabul eden zihniyetten hareketle düşünce
} ve ifade hürriyetine sinırlama getirmiştir (Alacakaptan, 1966). 
hükümleri ihlal ettikleri gerekçeleriyle kapatmıştır. Her iki kararda da özet olarak partilerin, azınlık yaratarak, milletin bölünmez bütünlüğüne zarar verme potansiyellerinin olduğu ifade edilmiştir (Perinçek, 2008, ss. 304 - 307). Oysa her iki parti de toplumda zaten var olan azınlıkların kültürel haklarının korunmasını dile getirmişlerdir. Modern Türkiye'nin resmi ideolojisi kapsamında homojen toplum oluşturma amacını tehlikeye düşürebilecek farklı kültürel taleplerin siyasal alanda ifade edilebilir olması, AYM eliyle engellenmiştir. Bu durum farklı kültürlere mensup kişilerin ötekileştirilmesine ve kültürel taleplerinin gayrimeşru ve tehlikeli görülmesine neden olmuştur. Devlet ve birey arasındaki bağlılık azalırken, 1961 Anayasası'nın özgürlükçü olduğu iddiasının da resmi ideoloji ile çatışan konularda geçerli olmadığı açığa çıkmıştır.

Diğer resmi ideoloji engeli 'laiklik' ilkesinin yorumu ile getirilmiştir. Türkiye'de milli görüş hareketininin ilk siyasal temsilcisi olan ve muhafazakâr, İslamcı çizgide yer alan MNP (Çaha ve Baykal, 2017, s.790), Atatürk İlke ve İnkılaplarına aykırı ve laiklik ilkesini ihlal eder nitelikte görülen talepleri olduğu gerekçesiyle (Perinçek, 2008, s. 301 - 302) AYM tarafından 1971 y1lında kapatılmıştır (AYM, E: 1971/1, K.1971/1, T: 20.05.1971; RG, S. 1472, G.14.01.1972). 1971 yılından itibaren bazı siyasilerin ifadesiyle 'bol gelen anayasal haklardan', resmî ideoloji sınırları dışında kalanlar geri alınmış ve ülkede 1961 Anayasası ile başlatılan Kemalist ideoloji merkezli kültürel revizyona hız verilmiştir. Milliyetçilik ve laiklik ilkelerinin dar yorumu ile AYM, anayasacılık fikrindeki teorik işlevine aykırı olarak (Gönenç, 2008, s. 268) resmi ideoloji çizgisi dışında kalanların önünü kapatmıştır. AYM'nin penceresinden kültürel hak talepleri, ülkede azınlık yaratma çabası ve Atatürk Milliyetçiliğinin ihlali olarak yorumlanmışken; dini inanç ve ibadet özgürlüğü kapsamındaki talepler de laiklik ilkesinin ihlali olarak yorumlanmıştır (Işık, 2012, ss. 337 - 345, 351 - 359).

12 Mart Muhtırasının etkisiyle yetkileri daraltılan AYM'nin ${ }^{20}$ 1974'e kadar siyasal, sosyal ve kültürel alanda takındığı vesayetçi tutumun tırmandığı görülmektedir. Resmi ideoloji taraftarı kesim 12 Mart Askeri Muhtırasıyla muktedir olduktan sonra, 'örf ve adetleri' bile geçmişi çağrıştırdığ 1 gerekçesiyle tahammül edilemez görmüş̧ür. 1973 yılında yayınlanan 1750 Sayılı Üniversiteler Kanunu 3. maddesinde üniversitelerin görevleri sayılırken "öğrencilerini bilim anlayışı kuvvetli, tarih şuuruna sahip, vatanına, örf ve adetlerine bağll, milliyetçi ve sağlam düşünceli aydınlar (...) olarak yetiştirmek" ifadesine de yer verilmiştir. Ankara Üniversitesi bu ifadede yer alan 'örf ve adetlerine bağll' sözünün, Anayasaya aykırılığını ileri sürerek, AYM’ye başvurmuştur.

AYM "Cumhuriyetimiz Milli şuur ve bütünlük içinde barışa ve insan hak ve özgürlüklerine dayall, memleket kalkınmasinı sosyal adalet ve Atatürk devrimleri ilkelerini amaçlayan siyasal bir varlıktır. Burada özellikle Atatürk Devrimleri (...) belirleneceği üzere, durgunluğun, alışkanlığın, hareketsizliğin tersidir. Devrimcilikte hiçbir zaman duraklama yoktur. Bilim ve tekniğin gelişmesiyle modern yeni toplum yaşamının koşulları da sürekli olarak değişikliğe uğrar. Kendisini bu değişikliğe uydurmayan, yani devrim yapamayan sosyal topluluklar çağın gerisinde kalmaya ve ileri toplumların sömürgesi olmaya mahkumdurlar. İste Atatürk devrimlerinde temel amaç geri kalmışlıktan kurtulmak, çağdaş uygarlık düzeyine ulaşmaktır (AYM, E: 1973/ 37, K: 1975/22, T: 14.02.19)" diyerek 'örf ve adetlere bağl1lı̆̆ı' durağanlık kapsamında saymış ve devrimcilik ilkesine aykırı görmüştür. Bu gerekçelerle ilgili ifadelerin iptaline karar vermiş, böylece üniversitelerin görevleri içinden 'örf ve adetlerine bağlı' gençler yetiştirmek çıkarılmış; üniversitelerin görevi “ögrrencilerini bilim anlayışı kuvvetli, tarih şuuruna sahip, milliyetçi, vatanına bağll ve să̆lam düşünceli aydınlar (...) olarak yetiştirmek" haline getirilmiştir. Üniversitelerin örf ve adete bağlı öğrenci yetiştirip yetiştirmemesi meselesi akademik mecralarda da tartışma konusu olmuştur. İstanbul

\footnotetext{
${ }^{20} 1971$ yılına kadar Anayasa Mahkemesi’nin Anayasa Değișiklikleri konusunda ne tür bir denetim yapacağı belirtilmediğinden hem esas hem şekil yönünden denetim yapabiliyorken 1971 yılında yapılan Anayasa değişikliği ile Anayasa değişiklikleri konusundaki yetkisi sadece esas denetimi yapma ile sınırlandırılmıştır. Bkz. Eser vd. 2012, s. 80.
} 
Üniversitesi'nde görev yapan bir doçent, örf ve adetlere bağl1 öğrenci yetiştirme fikri lehine görüş beyan edince; İstanbul Üniversitesi'nin Yönetim Kurulu, doçentin yanlış düşündüğüne oy birliği ile karar vermiş̧tir (Güngör, 1990, s. 107).

Bireylerin kendi tarihlerini, örf ve adetlerini öğrenmeleri temel haklarıdır. Ancak AYM resmi ideolojinin değerlerine uygun resmi tarih anlayışının zarar görmesinden çekinmiştir. Üniversitelerde, gençleri toplumsal kimliğin tarihi değerleriyle buluşturacak tarzda eğitim vermeyi 'çağdaşlık dışı', 'geri kalma nedeni' olarak değerlendirmiştir (AYM, E: 1973/ 37, K: 1975/22, T: 14.02.19). AYM bu kararında, toplumsal hafizanın silinmesinin ve ulus devletin modern batılı düşünce sisteminden aktardığı değerlerin toplumsal zihniyete yerleştirilmesinin önünü açmıştır. Elitist anlayışın bir yansıması olarak değerlendirilebilecek olan (Heywood, 2010, s.116) bu yaklaşımla düşünce özgürlüğü hiçe sayılmıştır. Bu durum örfünü adetini ve geçmişini bilmeyen, sadece batılı değerleri öğrenen nesilleri, kendilerine atalarına ve tarihlerine yabancılaştırırken, yeni düşünsel arayışlara yöneltmiş farklı ideolojilere açık hale getirmiştir.

12 Mart Muhtırasının oluşturduğu olağanüstü koşulların sona erdiği 1974 yılından itibaren resmî ideolojinin militanist döneminin durağanlığa yöneldiği süreçle paralel olarak AYM de resmî ideolojiye göre karar verme eğiliminden, hukuka uygun karar verme eğilimine yönelmiştir. Bu tutumunun bir yansıması olarak da Devlet Güvenlik Mahkemeleri'nin (DGM'lerin) Kuruluş Yasası'nın 1961 Anayasası'na aykırı olduğuna hükmederek söz konusu yasayı iptal etmiş̧tir ${ }^{21}$.

AYM'nin bir vesayet kurumu olmadığını düşünen yaklaşıma göre ise AYM 1961 Anayasası döneminde toplum içindeki gerilimleri hafifletmiştir. Bu yönüyle toplumsal açıdan bir tür emniyet sübabı işlevi yerine getirmiştir (Ünsal, 1980, s. 321). Ancak bu iddia gerçeklikle pek örtüşmemektedir. AYM toplumsal gerilimi yatıştıran bir işlev görmüş olsa toplumda huzurun sağlanması ve anti-demokratik girişimlerin yaşanmaması gerekirdi. Oysa AYM kararlarından sonra toplumsal gerilim önlenememiş ve 1980 Darbesi ile demokrasi kesintiye uğratılmıştır. 12 Mart Muhtırası sürecinde siyasal alanda gittikçe güçlenen askerler ve onların tavrına uygun tavır belirleyen AYM toplumu resmi ideoloji çizgisinde saf tutmaya zorlayarak vesayetçi bir işlev üstlenmiştir.

\subsection{Cumhuriyet Senatosu}

1961 Anayasası'nda parlamento çift meclislidir. Parlamentonun bir kanadı Millet Meclisi, diğer kanadı ise Cumhuriyet Senatosudur. Millet Meclisi'nde genel oyla seçilen 450 milletvekili varken, (Ankara tasarısının aksine) Cumhuriyet Senatosu üç farklı yolla gelen üyelerden oluşmuştur. Birinci grup üyeler 150 kişiden oluşmuş ve halk tarafından seçilmiştir. İkinci grup üyelerse 15 adettir ve Cumhurbaşkanı tarafından atanmışlardır. Hem halk tarafından seçilen hem de Cumhurbaşkanı tarafından atanan üyelerin görev süreleri 6 yıldır $^{22}$. Üçüncü grup ise MBK üyeleri ${ }^{23}$ ve eski Cumhurbaşkanlarıdır ${ }^{24}$. Bu üyeler ömür boyu görev yaparlar. 1961 Anayasası'nda ömür boyu görev yapacak eski Cumhurbaşkanları ve MBK üyelerine "tabii üyeler" denmiş̧tir (Özbudun, 2019, s. 43).

Seçimle gelmeyen üyeler Cumhuriyet Senatosu'nu demokratik meclis olmaktan çıkarmıştır. Çoğunluğu genel oyla seçilen kişilerden oluşan bu meclise aristokratik yapida bir meclis denemez. Ancak halkın seçimi olmadan Cumhuriyet Senatosu'nda yer alan üyelerin

\footnotetext{
${ }^{21}$ AYM, E: 1974/35, K: 1975/126, T: 06.05.1975. DGM'lerin nitelikleri ve Türk hukuk sistemindeki serüvenlerine ilişkin bkz. Şimşek, 2012, s. $112-113$

221961 Anayasası madde 73 gereği, görev süreleri 6 yıl olan Cumhuriyet Senatosu üyelerinin seçimleri 2 yılda bir yapılarak Cumhuriyet Senatosu'nun 1/3'ü değiştirilir.

${ }^{23} 13$ Aralı 1960 tarihli 157 sayılı Kurucu Meclis Teşkili Hakkında Kanun’un altında adları bulunan MBK üyeleri 23 kişidir. Cemal Gürsel Cumhurbaşkanı seçildiği için, Fikret Kuytak öldüğü için, Cemal Madanoğlu, Sitkı Ulay, Osman Köksal çeşitli sebeplerle tabii üyelikten çekilmişlerdir. 18 MBK üyesi tabii senatörlüğe devam etmiştir (Eroğul, 1977, s.22)

${ }^{24}$ Eski Cumhurbaşkanlarından Cemal Gürsel hastalık nedeniyle Cumhurbaşkanlığı görevini tamamlayamadan ayrılmış ve kısa süre sonra ölmüştür. Cevdet Sunay 1973'te görevini tamamlayarak tabii senatör olmuştur. İsmet İnönü de 1972'de CHP'den istifa edip tabii senatörlüğe geçmiştir. Celal Bayar ise tabii senatörlük teklifini reddetmiştir (Eroğul, 1977, s. 21).
} 
bulunması ve Senato'da sivil siyasal sistemi darbe ile durdurmuş kişilerin tabii üye olarak yer alması $^{25}$ ve halkın seçimiyle gelecek kişilerin Anayasa'nın 72. maddesi gereği 40 yaşını doldurmuş ve yüksek öğrenim yapmış kişiler arasından seçilmek zorunda olması Cumhuriyet Senatosu'nu seçkinci bir meclis haline getirmiştir (Erdoğan, 2003, s. 91) ve eleştirilere sebep olmuştur (Tanör, 2017, s. 395). Bu nedenle ikinci meclisin yapısı aristokratik ve demokratik meclis karmasıdır. Mecliste seçimle gelen üye sayısı seçimle gelmeyen üye sayısından fazla olsa da uygulamada, seçimle gelmeyen üyelerin (özellikle MBK üyelerinin) siyasal etkinliklerinin diğerlerinden fazla olduğu görülmüştür ${ }^{26}$.

1924 Anayasası'ndan farklı olarak 1961 Anayasası'nda çift meclisli parlamento öngörülmesinin temel nedeni kurucu iktidarın, 1924 Anayasası'nda düzenlenen tek meclisli yapıda DP'nin kamuoyu oluşturan kurumların çalışmasına mâni olduğunu ve hak ve özgürlükleri ihlal ettiğini düşünmesidir (Aydın ve Taşkın, 2014, ss. 81 - 82). 1961 Anayasası Kurucu Meclisi'nde etkili olan güç, 1950 seçimlerinden itibaren genel oy, gizli oy, açık sayım gibi demokratik ilkelerin seçimlerde uygulanmasıyla iktidarı kaybeden kesimin destekçileridir. Kurucu iktidarda etkin olan kesim demokratik yaşama dönüldüğünde azınlık olma durumunun değişmeyeceğini öngördüğünden (Tanör, 1986, s. 24) yasama organının tek başına demokratik çoğunluğun eline bırakılmasını istememiştir. Diğer bir ifade ile tek parti dönemi siyasi elitlerinin ve bürokratlarının kontrolü altında tutulacak bir sözde demokratik hukuk devleti inşa etmek amaçlanmıştır (TBMM, 2012, ss. 293 - 294).

Çift Meclis sistemini istemeyenler ise, ikinci meclisin, birinci meclisi denetlemesinin tıkanıklıklara neden olabileceğini ve yasama organının görevini kısa zamanda yapamamasına yol açacağını ileri sürmüşlerdir. İkinci meclisin tüm üyelerinin ya da bir kısım üyesinin seçimle iş başına gelmemiş olmasının, milletin temsili ilkesi ile bağdaşmadığını söylemişlerdir. Genellikle belirli zümrelerin egemen olduğu ikinci meclislerin demokratik açıdan sakıncalı olduğunu belirtmişlerdir (Özgişi, 2012, s. 51).

Kurucu Meclis'te CHP'nin etkili olmasıyla benimsenen genel yaklaşım 1924 Anayasası'nın getirdiği sistemin tek partili yaşama uygun olduğu, çok partili yaşamda ise çoğunluk otoriterliğine sebep olduğu yönündedir. Bu kapsamda 1946 - 1960 sürecinde demokrasinin ortadan kalktığını düşünen kesim, çift meclisli sistemin demokrasinin gelmesini sağlayacağını savunmuş ve anayasal bir reformla çift meclis sisteminin getirilmesini istemiştir (Öztürk, 2016, s. 179; Arsel, 1955, s. 67 - 70). Bu kesim dönemin gazetelerine iki meclisli sistemin faydalarını anlatan yazılar yazmış ve bu yönde kamuoyu oluşturmaya çalışmıştır ${ }^{27}$. Çift meclis isteyenlerden bir kısmı demokrasilerde seçilen kişilerin zekâ seviyesinin genelde düşük olduğu önyargısından hareketle, demokrasinin aristokratik yapıyı barındırmaya ziyadesi ile ihtiyacı olan bir sistem olduğunu ifade etmiş ve ikinci meclislerin bu aristokratik yapıyı kısmen sağladığını ileri sürmüşlerdir (Arsel, 1955, s.65 - 66). Temsilciler Meclisi'nde siyasal sisteme Cumhuriyet Senatosu'nu getirmek isteyenlerden bazıları, demokratik ülkelerde siyasi tercih ve kararlar oluşurken geniş katılımlı, kamuoyuna açık tartışmaların yapılmasının iktidarın sorumluluklarından sayılıyor olduğunu belirtmişlerdir. Ayrıca hükümetin yer almadığı bir organda hükümetin kararlarının tartışılmasının önünün açılmasının gerektiğini ileri sürmüşlerdir. Başka bir nedeninse yasaların ve hükümet çalışmalarının teknik mahiyetinin iyileştirilmek istenmesi olduğu belirtilmiştir (TMTD, C. III, s. 32, 364 - 369).

Ayrıca İstanbul ve Ankara tasarılarının ikisinde de yasama organının çift meclisli olması öngörülmüştür. Ancak Ankara tasarısında İstanbul tasarısından farklı olarak ikinci meclisin tamamen seçilmiş üyelerden oluşması tavsiye edilmiştir (Cumhuriyet Gazetesi, 06 Ağustos 1960).

\footnotetext{
${ }^{25}$ Kendilerini siyasal sistemin denetmeni/kontrolörü olarak gören kişiler oldukları ifade edilmek istenmiștir.

${ }^{26} 1961$ Anayasası'nın yürürlükte olduğu süreçte Meclisteki psikolojik üstünlük sayısal olarak temsilcisi az da olsa askerde olmuş̧ur (Karatepe, 2009, s. 225 - 232).

${ }^{27}$ Çeşitli gazetelerde ikinci meclis lehine yazılan yazılara ilişkin bkz. Özgişi, 2012, s. 50 - 51.
} 
1961 Anayasası'nda, yasama organındaki çoğunluk iradesine güvenilmeyen bir zihinsel arka plan ile hazırlanmasının da etkisi ile Millet Meclisi'ni denetleyecek/dengeleyecek bir fren mekanizması olarak Cumhuriyet Senatosu yasama erkinin ikinci parçası olarak düzenlenmiştir. Böylece parlamentodaki çoğunluk resmi ideoloji için tehdit oluşturacak nitelikte kanunlar yaparsa yasama organının ikinci kanadı olan Cumhuriyet Senatosu'nun bunu engelleyeceği düşünülmüştür (Aydın ve Taşkın, 2014, s. 93; Onar, 2003, s. 27 - 28; Parla, 2002, s. 42). Cumhuriyet Senatosu'ndan temel beklenti, toplumsal çoğunluğun temsilcilerine karşı İkinci Cumhuriyetin esaslarını ve Atatürk ilke ve inkılaplarını koruması olmuştur ${ }^{28}$. Diğger bir ifade ile resmi ideolojinin vesayet kurumu olarak sivil siyaseti denetleme ve siyasi iktidarın gücünü frenleme işlevini yerine getirmesi için Meclise ikinci bir kanat eklenmiştir (Yavuz ve Bülbül, 2012, s. 232).

1961 Anayasası'nın yürürlüğe girmesiyle 15 Ekim 1961'de yeniden demokratik yaşama dönülmüş ve seçimler yapılmıştır (Karatepe, 2009, s. 224). Böylece çift meclisli yasama organı uygulaması 1876 Anayasası döneminden sonra tekrar uygulama alanı bulmuştur. Uygulamada genel olarak milletvekili ve senatör dağılımları paralel olsa da üç dönemde bu paralelliğe aykırı durum oluşmuştur. 1961 seçimlerinde Millet Meclisi'ndeki 450 sandalyeden 158'ini Adalet Partisi (AP) alarak, Millet Meclisi'ne CHP'den daha az milletvekili göndermişken Cumhuriyet Senatosu'na 71 temsilci göndererek Senatodaki en çok sandalyeyi elde etmiştir ${ }^{29} .1961$ seçimlerinde CHP ise 173 milletvekili, 36 Senatör çıkarmıştır. 1973 seçimlerinde AP 149 CHP 185 milletvekili çıkarmışken, Senatoda AP 22, CHP 28 senatörlük kazanmışlar ve Millet Meclisi ile Cumhuriyet Senatosu üyeliklerindeki paralellik devam ederken iki y1l sonraki Senato seçimlerinde durum değişmiştir. 1975 yllında AP 27, CHP ise 25 senatör kazanmıştır. Bu duruma benzer şekilde 1977 seçimlerinde AP 189 milletvekili, CHP 213 milletvekili çıkarmış ve Senatoda AP 21, CHP 28 sandalye kazanmıştır. Ancak Senato'nun iki yıllık seçimlerinin 1979'da yapılmasiyla Senato'ya AP 33, CHP 12 senatör göndermiştir (Yavuz ve Bülbül, 2012, s. 239 - 240). Millet Meclisi'ndeki çoğunlukla Cumhuriyet Senatosu'ndaki çoğunluğun aynı dünya görüşünden partilerden oluşması ve partilerin sandalye dağılımının genel itibariyle Millet Meclisi ile Cumhuriyet Senatosu'nda paralellik arz etmesinin sebebi büyük ölçüde Millet Meclisi'nin ve Cumhuriyet Senatosu'nun seçimlerinin aynı gün yapılmasıdır

Cumhuriyet Senatosu, sıkıönetim ilanı ve sıkıönetim uygulamaları konularında 1961 Anayasası'nda öngörülen özgürlükleri koruyucu tutum takınmamış, Millet Meclis'in kararlarını derinlemesine irdelememiştir (Eroğul, 1977, ss. 84 - 85). Cumhuriyet Senatosu gerek 12 Mart Muhtırasına giden süreçte gerekse 12 Eylül Darbesi'ne giden süreçte ülkede şiddet olayları yükselirken toplumun farklı kesimlerinin taleplerini parlamentoya yansıtmadığ 1 gibi siyasi iktidarla toplumsal talepler arasında uzlaşı sağlanmasına aracılık da etmemiştir. Aksine toplumsal olaylardaki ideolojik katıl1k ve uzlaşmadan uzak kavgacı tutum aynen Cumhuriyet Senatosu'na da yansımıştır (Ö̈zgişi, 2012, s. 221).

Cumhuriyet Senatosu'nun varlığının siyasal sisteme olumlu bir katkısının (örneğin siyasiler arasında uzlaşı ortamı oluşturmak gibi) olmadığını ortaya koyan önemli bir vakıa ise, 1980 darbesinden önce Millet Meclisi ve Cumhuriyet Senatosu'nun birleşik oturumunda seçilmesi gereken Cumhurbaşkanının 115 tur seçim yapıldıktan sonra dahi seçilememiş olmasıdır (Pantül ve Yalçın, 1982, s. 175). Cumhuriyet Senatosu siyasal sistemdeki tıkanıklığı giderecek ve siyasal sistemi çalışır hale getirecek uzlaştırıcı işlev üstlenmemiştir.

Yapılan bir analize göre 1961 - 1977 yılları arasında yasalaşan metinlerin \%90’1 Millet Meclisi'nden Cumhuriyet Senatosu'na geldiği halinde hiçbir değişiklik olmadan yasalaşmıştır. Cumhuriyet Senatosu bu zaman zarfinda önüne gelen kanun metinlerinden \%7'si üzerinde

\footnotetext{
${ }_{28}$ Temsilciler Meclisi'nde konuşan, Alp Kuran ikinci Meclisten beklenen asli işlevi söyle dile getirmiştir: "Daha evvel de arz ettik ki, yeni kurulan ikinci Meclisin hiçbir yetkisi olmayacaksa, Atatürk devrimlerinin ve İkinci Cumhuriyetin koruyucusu olmayacaksa, bu meclisi kurmayalım." TMTD, C. III, 466.

29 AP'nin Cumhuriyet Senatosu'na (oyların \%35.4'ünü alarak) 70 senatör gönderdiğini ileri süren kaynaklar da bulunmaktadır (Özdemir, 1994, s. 155).
} 
değişiklik yapma ya da reddetme yetkisini kullanmıştır. Bu sebeple yasama sürecinde Cumhuriyet Senatosu'ndaki görüşmeler için gerekli olan 2 aylık süre kayıp zaman olarak nitelendirilmiştir (Eroğul, 1977, ss. 51 - 52). Bu bakımdan Cumhuriyet Senatosu'nun uygulamada kanunların daha nitelikli hazırlanması amacına hizmet ettiğini söylemek mümkün görünmemektedir.

1961 - 1980 döneminde seçilen 3 Cumhurbaşkanından 2'si ${ }^{30}$, bu dönemde kurulan 14 hükümetin 5'inin Başbakanı ve kurulan hükümetlerde toplam 65 bakan Cumhuriyet Senatosu üyelerinden çıkmıştır (Eroğul, 1977, s. 86). Cumhuriyet Senatosu özellikle Cumhurbaşkanlığı makamına ordu komutanlarından bir kişinin getirilmesi sürecinde kullanılan bir aracı kuruma dönüşmüştür (Özdemir, 1994, 195). Bu durum uygulamada Cumhuriyet Senatosu'nun çıkacak yasaların daha iyi düzenlenmesini sağlamak, anayasal hakların korunmasını sağlamak gibi işlevler yerine, yürütme erkinde aktif hale gelecek siyasal bağlantıları kurma işlevi yerine getirdiğini göstermektedir (Eroğul, 1977, s. 86). Cumhuriyet Senatosu'nun resmi ideoloji koruyuculuğu vasfinı, kanunları denetleyerek yerine getirmemiştir. Cumhuriyet Senatosu resmî ideoloji taşıyıcısı vasfını sivil siyaseti dizayn edecek ve siyasi iktidarın başına geçecek siyaset adamlarının seçildiği kurum işlevi üstlenerek yerine getirdiği görülmektedir.

\subsection{Devlet Planlama Teşkilatı}

XIX. yüzyıl ortalarından itibaren Avrupa'da devletleștirme toplumun bazı kesimleri tarafından sıklıkla talep edilir hale gelmiştir. Akademik camiada ise liberaller, devletleştirmeyi desteklemeseler de devlet müdahalelerinin düzenleyiciliğini kabul etmeye başlamışlar ve devletlerin ekonomik müdahaleleriyle hem düzenleyicilik hem de kalkınmayı sürekli kılma işlevi yerine getirebileceğini belirtmişlerdir. 1960'larda özellikle ücret politikasının ve gelir dağılımının düzeltilmesi, bölgeler arası denge, sosyal güvenlik gibi konularda devlet müdahalesinin önemi tüm dünyada kabul görür hale gelmiştir. Gelişmekte olan dünya ülkeleri ise bu dönemde devletçiliği 'planlamacılık' olarak benimsemiş ve kalkınmayı planlı devletçilikle özdeşleştirmişlerdir (İnsel, 1996, s. 21).

Türkiye için ve dolayısıyla DP için 1955 - 1958 yılları ekonomik olarak çok güç yıllar olmuştur. Hedeflenen ekonomik gelişme sağlanamadığı gibi 1950 - 1955 arası yakalanan ekonomik refah da kaybedilmiştir (Zürher, 2017, s. 330). Bu kapsamda ekonomik kalkınma bakımından yeni arayış içinde olan DP, planlı ekonomi programına geçmeye karar vermiş ve 1958 yılında ilgili programın Türkiye'ye uygulanmasını sağlamak konusunda yardım almak için konunun yabancı uzmanları ile anlaşmaya varmıştır. Mart 1960'da Ankara'da bu konuda çalışmalar başlamıştır ki 27 Mayıs Darbesi çalışmaların askıya alınmasına neden olmuştur (Mihçığlu, 1988, s. 121 - 122).

Ekonominin devlet tarafından planlanması Türkiye'deki Kemalist kesime yabancı bir fikir değildir. 1960 sonrası Kemalist sol kesim olarak bilinen ve Türkiye'deki aydın, bürokrat ve halk içinden önemli bir kesimi etkileyen ve DPT'nin ilk kadrosunda önemli ölçüde yer alan Yön Dergisi yazar ve çalışanlarınca, sosyal adalete uygun ekonomik kalkınmanın bel kemiği olarak görülen planlı ekonomi (At1lgan, 2008, ss. 598 - 600; Özdemir, 1993, ss. 257 - 270;) Cumhuriyetin ilk dönemlerinde de devletçilik şeklinde uygulanmıştır (İnsel, 1996, s. 20; Boratav, 1982, s. 59). Tek parti döneminin Kemalist ideoloji çerçevesinde ülkeyi dönüştürme sürecinde ekonomik açıdan tercih edilen devletçilik (Beriş, 2015, s. 203; Tekeli ve İlkin, 1982, ss. 79 - 88), 27 Mayıs Darbesi'nden sonra dünya konjonktürünün de etkisi ile Kemalist elitler

\footnotetext{
3027 Mayıs Darbesi'nden sonra 4. Cumhurbaşkanı seçilen Cemal Gürsel, rahatsızlığı nedeniyle 1966'da görevinden ayrılmıştır. 1966'da Genel Kurmay Başkanlığı görevinden emekliye ayrılan Cevdet Sunay, Cumhuriyet Senatosu'na Kontenjan Senatörü olarak atanmıs ve hemen akabinde 5. Cumhurbaşkanı olarak seçilmiștir. 5. Cumhurbaşkanı Cevdet Sunay, 7 y1llık görev süresi sona erdiğinde Cumhurbaşkanlığından ayrılmış ve tabii senatör olarak Cumhuriyet Senatosu'nda göreve başlamıştır. 6. Cumhurbaşkanı Fahri Korutürk ise 1968 yilında Cumhuriyet Senatosu'na kontenjan senatörü olarak atandiktan 5 y1l sonra 1973 y1lında Cumhurbaşkanı olarak seçilmiştir. 1980 yılında 7 yıllık görev süresini tamamladıktan sonra görevinden ayrılmış ve 1961 Anayasası gereği Cumhuriyet Senatosu'nda tabii senatör olarak göreve başlamıştır. Bkz. https://www.tccb.gov.tr/cumhurbaskanlarimiz/ (Erişim tarihi: 29.08.2020).
} 
için ekonomi alanında tekrar kurtarıcı bir yaklaşım olarak görülmüştür . Her ne kadar ekonomiyi devlet güdümüne verme amacı aynı olsa da 1930'ların devletçiliği ile 1960'lar sonrasının devletçilik anlayışları tamamen aynıdır denemez. Her iki devletçilik anlayışı arasındaki temel farksa: 1930'ların devletçiliğinin devletin öncülüğü fikrine, 1960'ların devletçiliğinin ise özel kesimin öncülüğüne yönelik olmasıdır (Önder, 1998, ss. 85 - 86).

Zinde kuvvetler, DP'nin ekonomik alanda gelişme yerine sadece büyüme gerçekleştirdiğini ve baştan savma bir ekonomi politikası yürüttüğüne inanmışlardır (Ahmad, 1992, s. 132). Bu nedenle 1961 Anayasası hazırlanırken, toplumsal çoğunluğun desteklediği iktidarı, ekonomi alanında kontrol altında tutacak bir kurum oluşturmaya sıcak bakılmıs DPT anayasal bir kurum olarak siyasal sisteme eklenmiştir. 1961 Anayasası'nın ekonomik ağırlık merkezi, planlı devletçi ekonomi olmuştur. Her ne kadar planlamanın gerçekleşmesi için üretimin toplumsallaşması ve üretim araçlarının toplumun kontrolüne geçmesi gerektiğini diğer bir ifade ile üretim araçları üzerindeki özel mülkiyetin tamamen kaldırılması gerektiğini düşünenler olsa da (Küçük, 1975, ss. 17, 27 - 32) 1960 - 1980 aras1 dönemde çağdaşlaşma adeta ekonomik alanda planlı kalkınma ile özdeşleşmiş̧ir. Hızlı bir kalkınmanın taşıyıcısı olma misyonu yüklenen devletçi politikaların (Beriş, 2015, s. 203), anayasal bir kurum haline getirilen DPT tarafindan şekillendirilmesi hedeflenmiştir (Mıhçığlu, 1988, s. 122).

Siyasal sistem içinde DPT'ye o denli ağırlık verilmek istenmiştir ki DPT’nin kurulma sürecinde en çok tartışılan husus bu kurumun siyasetten tamamen bağımsız ve hukuken hükümeti bağlar nitelikte karar verebilen bir kurum olup olmaması olmuştur. Nihayetinde hükümet DPT'nin planları ile bağlı kılınmasa da DPT, klasik bakanlık örgütlenmelerinden farklı olarak doğrudan Başbakanlığa bağlı şekilde yapılandırılmıştır (Kaya, 2012, s. 222). DPT'nin çalışma usulü şu şekilde öngörülmüştür: Başbakan'ın talebiyle ekonomik plan hazırlanmaya başlanır, hazırlanan plan Yüksek Planlama Kurulu'nda incelenir. İncelemeden sonra Bakanlar Kurulu'nun onayına sunulur. Onaylanan plan TBMM gündemine alınır ${ }^{31}$. Siyasetin sürece dahil olduğu bu sistemde DPT'nin kararlarının Bakanlar Kurulu'nun onayına tabi k1lınması, bu kurumun sivil iktidar üzerinde resmî ideoloji taraftarlarının beklediği ölçüde etkin olamamasına neden olmuştur (Yıldırım, 2015, ss. 27 - 29). DPT'nin Yüksek Planlama Komisyonu üyeleri bu durumun kendi konumlarını pasifleştirdiğini fark ederek bir süre sonra kapsamlı siyasal yetkiler istemeye başlamışlardır (Karpat, 2017, s. 266).

Ekonomik planlama Türkiye'nin ekonomisini ve toplumsal yapısını önemli ölçüde tarımsal olmaktan çıkarıp ithal ikameci endüstri merkezli hale getirmiştir (Ahmad, 1992, s. $133)^{32}$. Bu süreçte siyasi iktidar DPT’nin ekonomik tercihlerini dikkate almış ancak bu tercihlerle bağlı kalmamıştır. Bir vesayet organı olarak tasarlanan ve anayasada yer verilen bu kurum, resmi ideoloji taraftarlarının beklediği ölçüde siyasi iktidar üzerinde bask1 oluşturamamış ve siyasi iradenin kontrolü olmaksızın ülkenin ekonomik yapısına yön verememiştir.

\subsection{Cumhurbaşkanlığı}

1924 Anayasası'nda Cumhurbaşkanının Meclis çoğunluğu tarafından bir yasama dönemi için seçileceği öngörülmüştür ${ }^{33}$. Böylece Cumhuriyetin ilanı ile birlikte siyasal sisteme dahil olan Cumhurbaşkanlığı makamı, 1924 Anayasası dönemi boyunca, Meclis çoğunluğunu elde eden parti içinden belirlenmiştir. Seçilen Cumhurbaşkanları siyasal çoğunlukla yakın ilişki içinde olmuşlardır. CHP iktidarı döneminde Mustafa Kemal Atatürk ve İsmet İnönü, DP iktidarı döneminde ise Celal Bayar Cumhurbaşkanlığ yaparken hem iktidar partisinin lideri hem de Cumhurbaşkanı olarak devletin başı olma misyonlarını beraber yerine getirmişlerdir.

\footnotetext{
3130/09/1960 gün 91 Sayılı Devlet Planlama Teşkilatının Kurulması Hakkında Kanun madde 13 - 14.

${ }^{32}$ Faal nüfus içindeki 'hizmet' sektörünün payı 1960 'da \%15 iken 1980 'de bu pay \%29,5'e yükselmiş ayrıca hizmetler/sanayi istihdam payının oranı 1960'da \%1,60 iken 1980'de \%2,36'ya çıkmıștır. (Boratav, 2017, s. 388).

${ }^{33} 1924$ Anayasası madde 31: “Türkiye Cumhurbaşkanı Büyük Millet Meclisi Kamutayı tarafindan ve kendi üyeleri arasından bir seçim dönemi için seçilir. Cumhurbaşkanlığı görevi yeni Cumhurbaşkanının seçimine kadar sürer.”
} 
Cumhurbaşkanı ile Meclis çoğunluğunun aynı dünya görüşünden olmaları DP iktidara geldikten sonra CHP tarafından eleştiri konusu yapılmıştır. Celal Bayar'ın DP'li bir siyasetçi olarak Başbakan Adnan Menderes'le yakın ilişki içinde olması ve ülke yönetiminde uyumlu hareket etmesi muhalefet tarafından Bayar-Menderes oligarşisi olarak yorumlanmıştır. Oysa ki CHP iktidarı döneminde de cumhurbaşkanları ve başbakanlar aynı partiye mensup oldukları gibi siyasal kararlarda birlikte hareket etmişlerdir (Ahmad, 1992, s. 114).

1961 Anayasası'nda Cumhurbaşkanlığı makamını tarafsız ve partiler üstü bir kurum olarak şekillendirilmiştir (Gönenç, 2017, s. 1 - 6). Parlamenter sistemin etkin kılınması için Cumhurbaşkanının tarafsız olması gerektiği (Öztürk, 2016, s. 188) iddiasıyla Cumhurbaşkanlığ ile demokratik çoğunluğun ilişkisi koparılmıştır. Cumhurbaşkanı 1924 Anayasası'nda Meclis çoğunluğu tarafindan bir yasama dönemi için seçilirken ${ }^{34}$, 1961 Anayasası'nda bir yasama döneminden daha uzun süre için ( 7 yıl için) seçilir hale gelmiştir. Ayrıca Cumhurbaşkanı seçilen kişinin partisi ile ve TBMM ile ilişkisi kesilere ${ }^{35}$ yasama çoğunluğundan bağımsızlaştırılması amaçlanmıştır. Her iki Anayasa döneminde de Cumhurbaşkanının kanunları veto yetkisi geciktirici veto niteliğinde olmuştur ${ }^{36} .1961$ Anayasası'nda Cumhurbaşkanının Meclis çoğunluğu tarafından seçilmesi ve üst üste iki defa seçilememesi öngörülmüş böylece makamın tarafsızlı̆̆ ve partiler üstü olması amaçlanmıştır ${ }^{37}$.

1961 Anayasası yürürlüğe girdikten sonra demokratik sisteme geçildiğinde kurulan Meclisin, siyasal ve anayasal açıdan karşılaştı̆̆ 1 ilk sorun Cumhurbaşkanlığ makamının vesayetçi bir organ mı olacağı yoksa demokratik bir organ mı olacağı sorunu olmuştur. Şöyle ki darbe sonrasında yapılan ilk demokratik seçim olan 15 Ekim 1961 seçimlerinde CHP 173, DP'nin devamı niteliğindeki AP 158, Yeni Türkiye Partisi (YTP) 65, Cumhuriyetçi Köylü Millet Partisi (CKMP) 54 milletvekili çıkarmıştır. Seçimlerin akabinde demokratik yoldan seçilip gelen milletvekillerinin sayısal üstünlügü ile Meclis'teki psikolojik üstünlüğe sahip olan askeri kesim arasında Cumhurbaşkanının kim olacağı konusunda tartışma yaşanmıştır. CHP'li olanlar dışındaki milletvekilleri Ali Fuat Başgil'in Cumhurbaşkanı olmasını isterken (Karatepe, 2009, s. 225) askerler Ali Fuat Başgil'in kesinlikle Cumhurbaşkanı olmasını istememişlerdir. Bu süreçte Ali Fuat Başgil aday olmaması için askerler tarafından tehdit edilmiştir (Ulay, 1968, ss. 233 - 234; Özdemir, 1994, ss. 175 - 176). Kriz demokratik sistemin devam edebilmesi adına AP'li vekillerden bir kısmının ikna edilmesiyle ve Cemal Gürsel'in Cumhurbaşkanı seçilmesi ve İnönü'nün başbakanlığında CHP-AP koalisyonuna dayanan hükümetin kurulmasıyla aş1lmıştır (Ahmad, 1992, s. 2014; Aydın ve Taşkın, 2014, s. 101).

1961 Anayasası döneminin ilk Cumhurbaşkanı askerin açık baskısı ile demokratik olmayan yöntemlerle belirlenmiş ve darbecilerin lider olarak sonradan ikna ettikleri Cemal Gürsel darbeci askerlerin temsilcisi olma siyasal misyonunun verdiği güçle Cumhurbaşkanı olarak seçilmiştir. Böylece 1921 ve 1924 Anayasası döneminde başlamış olan asker kökenli Cumhurbaşkanı geleneği 1961 Anayasası döneminde de üstelik demokratik oluşuma sahip meclisle bağlantısı tamamen koparılarak devam ettirilmiştir (Tanör, 2017, s. 123). 1961 Anayasası döneminde Cumhurbaşkanı seçilen Cemal Gürsel, Cevdet Sunay ve Fahri Korutürk hem asker kökenli hem de siyasi parti üyesi olmayan kişilerdir (Gönenç, 2017, s. 1).

\footnotetext{
${ }^{34} 1924$ Anayasası madde 31: “Türkiye Cumhurbaşkanı Büyük Millet Meclisi Kamutayı tarafindan ve kendi üyeleri arasından bir seçim dönemi için seçilir. Cumhurbaşkanlığl görevi yeni Cumhurbaşkanının seçimine kadar sürer.”

351961 Anayasası madde 95: “Cumhurbaşkanı, Türkiye Büyük Millet Meclisince, kırk yaşını doldurmuş ve yüksek ögrenim yapmış kendi üyeleri arasından, üye tam sayısının üçte iki çoğunluğu ile gizli oyla yedi yıllık bir süre için seçilir; ilk iki oylamada bu çoğunluk sağlanamazsa, salt çoğunlukla yetinilir.

Bir kimse arka arkaya iki defa Cumhurbaşkanı seçilemez.

Cumhurbaşkanı seçilenin partisi ile ilişiği kesilir ve Türkiye Büyük Millet Meclisi üyeliği sıfatı sona erer."

${ }^{36} 1924$ Anayasası madde 35, 1961 Anayasası madde 93.

37 Gerek Anayasa Komisyonu'nda gerekse Temsilciler Meclisi’nde Cumhurbaşkanı'nın halk tarafından seçilmesi önerilmiştir. Ancak bu seçimin partiler üzerinden yürütülmesi ve böylece Cumhurbaşkanı'nın siyasallaşması ihtimali ve ayrıca halkın desteğini arkasına alan Cumhurbaşkanı'nın tarafsız kalmayarak aktif siyaset yürütmek istemesi ihtimali nedeniyle bu öneri kabul edilmemiştir (Öztürk, 2016, s. 190).
} 
12 Mart Muhtırası sürecinde Cumhurbaşkanının tutumu da Cumhurbaşkanlığı makamının vesayetçi bir işlev üstlendiğine örnek teşkil eder niteliktedir. 12 Mart Muhtırası verilirken Cumhurbaşkanı olan Cevdet Sunay (eski Genel Kurmay Başkanı'dır) kendisini bu makama seçmiş olan ${ }^{38}$ parlamento çoğunluğuna karşı askerlerin safında yer almış ve muhtırayı önlemeye yönelik güçlü bir çaba içinde olmamıştır (Birand vd, 2008, s. 208 - 216). Bu durum Cumhurbaşkanı'nın sivil siyaset üzerinde askeri vesayet etkisini desteklediğini göstermektedir. Diğer bir ifade ile sivil siyasetten yetki alan Cumhurbaşkanı demokrasi safından ayrılıp, vesayet muhafızlarının safına geçmiştir.

1961 Anayasası'ndaki düzenlemelere ve Cumhurbaşkanı'na tanınan yetkilere bakılarak, Cumhurbaşkanlığı makamının vesayet organı olarak tasarlandığını söylemek fazla iddialı görünebilir. Ancak yukarıda da örnekleri verildiği üzere Cumhurbaşkanlığı kurumuna siyasetin yüklediği anlam ve bu kurumda görev yapanların gerek mesleki geçmişleri itibariyle asker kökenli olmalarının siyaset psikolojisi açısından oluşturduğu resmî ideoloji baskısı gerekse siyasal sistem içindeki tutum ve davranışları bu kurumun uygulamada "vesayet muhafizlı̆̆ (Kılıç, 2017) vasfi taşıyan bir kurum haline geldiğini göstermektedir.

\section{Tartışma ve Sonuç}

1961 Anayasası Kurucu İktidarı, demokrasi teorisi açısından bir ikilemin içine doğmuştur. Bir tarafta döneminin koşullarında (ikinci Dünya Savaşı sonrasında tüm dünyada yükselen liberal özgürlük rüzgarının etkisi ile) insan haklarını toplumun her kesimine tanıyan çoğulcu demokratik bir sistem getirme ideali diğer tarafta (bir darbe anayasası olarak) resmî ideoloji çerçevesi içinde demokratik görünümlü vesayetçi bir siyasal sistem kurma amacı yer almıştır.

Doktrinde 1961 Anayasası için çoğulcu demokrasi getirdiğini savunanlar:

- 1961 Anayasası ile geniş temel hak ve özgürlük listesi getirildiğini ve temel hak ve özgürlüklere ilişkin önemli korumalara yer verildiğini,

- 1961 Anayasası ile birey-devlet ilişkisinde bireyin daha önemli tutulduğunu,

- Seçim sisteminde nisbi temsil sistemine geçildiğini ve siyasal katılımın önünün açıldığını, ileri sürmüşlerdir (Aldıkaçtı, 1964, ss. 10 - 21, Özbudun ${ }^{39}, 2016$, ss. 42 - 43; Tanör, 2017, ss. 378 - 424). Bu görüşe katılmayan ve 1961 Anayasası ile vesayetçi anlayışın temellerinin atıldığını savunanlar ise:

- Temel hak ve özgürlüklerin toplumun tüm kesimlere eşit olarak tanınmadığını,

- Bazı toplumsal kesimlerin siyasal katılımının engellendiğini,

- Toplumsal çoğunluğun resmî ideolojiyi desteklemediği görüldüğünden, siyasi iktidarın tek başına toplumsal çoğunluğun eline bırakılmaması için nispi temsil sisteminin benimsendiğini,

- Siyasal iktidarın vesayet kontrolü altında tutulabilmesini sağlamak üzere 1961 Anayasası ile bazı kurumsal düzenlemelerin yapıldığını, ileri sürmektedirler (Özbudun, 2019, s. 43; Erdoğan, 2003, s. 90 - 114; Aydın ve Taşkın, 2018, s. 89 - 99).

Bu iddiaların gerçekliği sorgulanırken öncelikle 1961 Anayasası'nın hazırlanış sürecinde Anayasaya yüklenen felsefi arka plan ele alınmıştır. Kurucu Meclis'te CHP'li olmayanların bask1 altına alınması ve DP temsilcisinin bulunmaması ile 1961 Anayasası'nı DP muhalifi görüşlerin şekillendirdiği anlaşılmıştır.

\footnotetext{
${ }^{38}$ Cevdet Sunay, dönemin Başbakanı AP lideri Süleyman Demirel'in önerisi ile AP ve CHP'li milletvekillerinin desteği ile Cumhurbaşkanı seçilmiştir (Birand vd., 2008, s. 138 - 142).

39 Ergun Özbudun, Türk Anayasa Hukuku isimli kitabının 2016 yılındaki baskısında 1961 Anayasası hakkında vesayetten bahsetmezken 2019 yılı basımında 1961 Anayasası'nın çoğulcu toplum yapısı ile birlikte vesayetçi bir yapı getirdiğini eklemiş̧tir. Görülmektedir ki bu konudaki görüşü değişmiştir.
} 
DP'nin son dönemlerinde muhaliflerce eleștirilen 1924 Anayasası'nın çoğunlukçu demokrasi sistemi getirmiş olmasına tepki olarak, 1961 Anayasası çoğulcu demokrasinin getirilmesi için temel hak ve hürriyetler genişletilmiş ve nispi çoğunluk seçim sistemi benimsenmiştir. Ancak nispi seçim sistemi ülkenin istikrarlı yönetilememesine neden olmuş, bu süreçte koalisyonların içindeki partilerin iktidar mücadelelerinin ülkenin toplumsal huzurunun ve ekonomik refahının sağlanamamasında etkili olduğu görülmüştür.

1961 Anayasası ilk halinde temel hak ve özgürlükleri oldukça geniş ölçüde tanımış ancak toplumun her kesimi için aynı korumayı öngörmemiştir. Özellikle muhafazakar kesimi ilgilendiren ibadet, dini ayin ve törenlere ilişkin "kamu düzeni ve genel ahlaka aykırllık" gibi geniş yorumlanmaya müsait özel sınırlandırma nedenleri öngörülmüştür. Ayrıca AYM temel hak ve özgürlükleri resmi ideoloji dışında gördüğü kesimler için dar yorumlamış bazı davalarda tamamen yok saymıştır. Anayasa ile tanınan temel hak ve hürriyetler Anayasa tarafından kurulan vesayetçi kurumlar aracılığıla belirli kesimler için kullandırılmamıştır. Bu nedenle gerçek anlamda çoğuluculuktan bahsetmek doğru görünmemektedir.

MGK, AYM, Cumhuriyet Senatosu, DPT ve Cumhurbaşkanlığı vesayetçi anlayışla düzenlenen kurumlar olmuştur. MGK, 1960 - 1980 döneminde sivil siyasetin üzerinde her daim 1960 Darbesi'nin ve üç darağacının gölgesi olmuştur. AYM özellikle 12 Mart Muhtırası sonrasında etkin şekilde resmi ideoloji muhafizlığ işlevi yerine getirmiştir. Cumhuriyet Senatosu resmi ideolojiye uygun hareket edecek kişilerin Cumhurbaşkanları ve hükümet üyeleri olmaları için basamak olmuştur. Cumhurbaşkanlığı ise siyasal temsilden koparılmış ve eski askerlerin atandığı bir merci haline gelerek vesayet muhafizlı̆ $l$ görevi üstlenmiştir. DPT ise kararlarının hükümeti bağlayıcı olmaması sebebiyle sivil siyaset üzerinde kontrol işlevi yerine getirememiştir.

27 Mayıs Darbesiyle sivil siyasetin üzerine düşen asker süngüsü ve üç darağacının gölgesi, 1961 Anayasası ile getirilen vesayetçi kurumlar aracılığıyla kalıcılaştırılmaya çalışılmıştır. Toplum ve siyasal sistem üzerinde oluşturulmaya çalışılan vesayet zihniyeti, hazırlandığı andan yürürlükten kalktığı ana kadar 1961 Anayasası dönemine hâkim olmuş ve gelecek dönemlere miras kalmıştır.

\section{Kaynakça}

Ahmad, F. (1992). Demokrasi Sürecinde Türkiye 1945 - 1980. İstanbul: Hil Yayınları.

Akın, R. (2010). Türk Siyasal Tarihi. İstanbul: On İki Levha Yayınları.

Akgün, S. (1981). Şapka Kanunu, Tarih Araşttrmaları Dergisi, 14(25), 69-79. doi: 10.1501/Tarar_0000000360

Alacakaptan, U. (1966). Demokratik Anayasa ve Ceza Kanunu'nun 141 ve 142. Maddeleri, Ankara Üniversitesi Hukuk Fakültesi Dergisi, 22(1), 1966, 3. -20.doi: 10.1501/Hukfak_0000001361

Aldıkaçtı, O. (1964). Anayasa Hukukumuzun Gelişmesi ve 1961 Anayasası. İstanbul: Bahar Matbaas1.

Arsel, İ. (1955). Çift Meclis Sisteminin Memleketimizde Tatbiki Hususunda Bazı Düşünceler, Ankara Üniversitesi Hukuk Fakültesi Dergisi, 11(3-4), 59-99. doi: 10.1501/Hukfak_0000001260

Arsel, İ. (1965). Anayasa Hukukunun Umumi Esasları. Ankara: Yayınevi Belirtilmemiş.

Atılgan, G. (2008). Yön-Devrim Hareketi, T. Bora ve M. Gültekingil (Ed.), Modern Türkiye'de Siyasal Düşünce: Sol içinde (597-600). İstanbul: İletişim Yayınları.

Aydın S. ve Taşkın, Y. (2014). 1960'dan Günümüze Türkiye Tarihi. İstanbul: İletişim Yayınlar1. 
AYM, 08.04.1963 günlü karar, RG, Sayı: 11456, Gün 17 Temmuz 1963.

AYM, E: 1973/ 37, K: 1975/22, T: 14.02.19.

AYM, E:1971/3, K:1971/3, T: 20.07.1971.

AYM, E:1979/1, K:1980/1, T: 08.05.1980.

Beriş, H. E. (2015). Tek Parti Döneminde Devletçilik. Ankara: Tezkire Yayınları.

Bianet (2010). Bugünkü Vesayet Rejiminin Temelleri 1961 Anayasast Ile Atıld. https://bianet.org/bianet/siyaset/122191-bugunku-vesayet-rejiminin-temeli-1961-anayasasiile-atildi (Erişim tarihi: 18.05.2019).

Birand M. A., Dündar C. ve Çaplı B. (2008). 12 Mart İhtilalin Pençesinde Demokrasi. Ankara: İmge Kitapevi.

Boratav, K. (2017). Emperyalizm, Sosyalizm ve Türkiye. İstanbul: Yordam Yayınları.

Boratav, K. (1982). Türkiye'de Devletçilik. Ankara: Savaş Yayınları.

Cumhuriyet Gazetesi, 06 Ağustos 1960.

Çaha, Ö. ve Baykal, Ö. (2017). Milli Görüş Hareketinin Kuruluşu: Türk Siyasetinde Milli Nizam Partisi Deneyimi. Gazi Üniversitesi İktisadi ve İdari Bilimler Fakültesi Dergisi, 19(3), 788-806. doi: belirtilmemiş.

Çakmak, D. (2007). Forum Dergisi: 1954 - 1960 (Doktora tezi). Ankara Üniversitesi, Ankara.

Çaylak, A. ve Baran, H. (2017). Türkiye'de Kemalist Rejimin Ordu ve Anayasa ile Pekişmesi ve Darbeler Arası Dönem (1960-1970). A. Çaylak, M. Dikkaya, C. Göktepe ve H. Kapu (Ed), Türkiye'nin Siyasal Hayatı içinde (437 - 484), Ankara: Savaş Yayınevi.

Dal, K. (1986). Türk Esas Teşkilat Hukuku. Ankara: Bilim Yayınları.

Erdoğan, M. (2003). Anayasalar ve Siyaset. Ankara: Liberte Yayınları.

Erim, N. (2005). Günlükler 1925-1979. İstanbul: YKY Yayınları.

Eroğul, C. (1977). Türk Anayasa Düzeninde Cumhuriyet Senatosunun Yeri. Ankara: Üniversitesi Siyasal Bilgiler Fakültesi Yayınları.

Eroğul, C. (2000). Anatüzeye Giriş. Ankara: İmaj Yayınları.

Eser B., Baltacı C. ve Arslan M. (2012). Türk Siyasal Sisteminde 1960 Müdahalesi ve Vesayetin Kurumsallaşması Üzerine Bir Analiz Denemesi, SDÜ Fen Edebiyat Fakültesi Sosyal Bilimler Dergisi, 25, 69-97. Doi: belirtilmemiş

Gönenç, L. (2008). Ergun Özbudun'a Armağan. Ankara: Yetkin Yayınları.

Gönenç, L. (2010). Yasaların Anayasaya Uygunluğunun Yargısal Denetimi ve Anayasa Yargısı. Ankara: TEPAV Yayınları.

Gönenç, L. (2017). Partili Cumhurbaşkanı. Ankara: TEPAV Politika Notu.

Göze, A. (1970). Baskıya Karşı Direnme Hakkının Kabul Edildiği Pozitif Hukuk Metinleri ve Anayasalar. Ístanbul Üniversitesi Hukuk Fakültesi Mecmuasl, 36(1-4), 28-43. doi: belirtilmemiş.

Gözler, K. (2000). Türk Anayasa Hukuku. Bursa: Ekin Yayınevi.

Güngör, Erol.(1990). Kültür Değişmesi ve Milliyetçilik. İstanbul: Ötüken Yayınları.

Heywood, A. (2010). Demokrasi (B. B. Özipek, B. Şahin, M. Yıldı, Z. Kopuzlu, B. Seçilmişoğlu ve A. Yayla, Çev.). B. Kalkan (Ed), Siyaset (101-122). Ankara: Adres Yayınları. 
Hirschl, R. (2004). TowardsJuristocracy: The Originsand Consenquences of the New Constituonalism. Cambridge: Harward University Press.

Işık, H. M. (2012). Anayasa Mahkemesi Kararlarında Devletin Resmi Ídeolojisi. Ankara: Adalet Yayınevi.

İnsel, A. (1996). Düzen ve Kalkınma Kıskacında Türkiye. İstanbul: Ayrıntı Yayınları.

İnsel, A. (2001). Modern Türkiye'de Siyasi Düşünce. İstanbul: İletişim Yayınları.

İpekçi A. Ve Coşar Ö. S. (2010), İhtilalin İçyüzü. İstanbul: Türkiye İş Bankası Yayınları.

Kaçmazoğlu, B. (2012). Demokrat Parti Dönemi Toplumsal Tartışmaları. İstanbul: Doğu Kitapevi.

Karatepe, Ş. (2009). Darbeler Anayasalar ve Modernleşme. İstanbul: İz Yayıncılık.

Karatepe, Ş. (2018). Tek Parti Dönemi. Ankara: A Kitap Yayınevi.

Karpat, K. (2017). Kimlik ve İdeoloji. İstanbul: Timaş Yayınları.

Kaya, Y. (2012). Kapitalizmi Planlamak-Türkiye'de DPT'nin Dönüşümü, İnsan ve Toplum, 2(3), s. 221 - 224. Doi: dx.doi.org/10.12658/human.society.2.3.D0035

Kılıç, M. (2017). Cumhurbaşkanlığı Kararnamesi, Türkiye Gazetesi, https://m.turkiyegazetesi.com.tr/yazarlar/prof-dr-muharrem-kilic/595941.aspx (Erişim tarihi: 15.01.2020).

Kili, S. ve Gözübüyük, Ş. (2006). Senet- Ittifak'tan Günümüze Türk Anayasa Metinleri. İstanbul: Türkiye İş Bankası Yayınları.

Kili, S. 27 Mayıs 1960 Devrimi Kurucu Meclis ve 1961 Anayasası. İstanbul: Boyut Yayınları.

Köker, L. (2012). Modernleşme Kemalizm ve Demokrasi. İstanbul: İletişim Yayınları.

Küçük, Y. (1975). Planlama, Kalkınma ve Türkiye. İstanbul: Bilim Yayıncılık.

Mihçığlu, C. (1988). Yine Devlet Planlama Örgütünün Kuruluşu Üzerine. Ankara Üniversitesi SBF Dergisi, 43(1), 113-146. Doi: 10.1501/SBFder_0000001500

Onar, E. (2003). Kanunların Anayasaya Uygunluğunun Siyasal ve Yargısal Denetimi ve Yargısal Denetim Alanında Ülkemizde Öncüler. Ankara: Basımevi Belirtilmemiş.

Önder, İ. (1998). 1961 Anayasası'nın Ekonomik Modeli. Suna K. (Ed), 27 Mayıs 1960 Devrimi Kurucu Meclis ve 1961 Anayasası içinde. İstanbul: Boyut Yayınları.

Özbudun, E. (2012). Türkiye'de Anayasa Yargısının Doğuşu. Liberal Düşünce Dergisi, 68, 518. Doi: belirtilmemiş.

Özbudun, E. (2016). Türk Anayasa Hukuku. Ankara: Yetkin Yayınları.

Özdemir, H. (1993). Sol Kemalizm. İstanbul: İz Yayınc1lı.

Özdemir, H. (1994). Ordunun Olağandışı Rolü. İstanbul: İz Yayıncılık.

Özgişi, T. (2012). Türk Parlamento Tarihinde Cumhuriyet Senatosu. Ankara: TBMM Kültür ve Sanat Yayınları.

Özutku, M. (2016). 1961 Kurucu Meclisi. İstanbul: Oniki Levha Yayıncılık.

Pantül, M. ve Yalçın, B. S. (1982). Türk Parlamento Hukukunda İkinci Meclisler. Ankara: Cumhuriyet Senatosu Vakfı Yayınları.

Parla, T. (2002). Türkiye'de Anayasalar, İstanbul: İletişim Yayınevi. 
Perinçek, D. (2008). Anayasa ve Partiler Rejimi Türkiye'de Siyasal Partilerin Iç Düzeni ve Yasaklanması. İstanbul: Kaynak Yayınları.

Şimşek, M. (2012). 1982 Anayasası'nda Yargı Bağımsızlığı ve Yargl Tarafsızlı̆̆ (Yayımlanmamış yüksek lisans tezi). Ankara Üniversitesi, Ankara.

Tanör, B. (1986). İki Anayasa 1961-1982. İstanbul: Beta Yayınları.

Tanör, B. (2017). Osmanlı - Türk Anayasal Gelişmeleri. İstanbul: YKY Yayınları.

Tekeli, İ. ve İlkin, S. (1982). Uygulamaya Geçerken Türkiye'de Devletçiliğin Oluşumu. Ankara: Orta Doğu Teknik Üniversitesi İdari İlimler Fakültesi Yayını.

Tuluoğlu, F. (2017). CHP'nin 14. Kurultayı ve İlk Hedefler Beyannamesi, Ankara Üniversitesi Türk Inkılap Tarihi Enstitüsü Atatürk Yolu Dergisi. 15(60), 277-310. doi: belirtilmemiş.

Tuluoğlu, F. (2019). 27 Mayıs'1 Restore Etme Projesi: Tedbirler Kanunu (1962), Yakın Dönemde Türkiye Araştırmaları Dergisi. (35), 1- 26. doi: 10.26650/YTA2019-583690.

TBMM. (2012). Ülkemizde Demokrasiye Müdahale Eden Tüm Darbe ve Muhtıralar ile Demokrasiyi İslevsiz Kılan Diğer Bütün Girişim ve Süreçlerin Tüm boyutları ile Araştırılarak Alınması Gereken Önlemlerin Belirlenmesi Amacıyla Kurulan Meclis Araştırması Komisyonu Raporu.

TMTD, C. III.

Toplu, A. (1976). Anayasada Milliyetçilik Mücadelesi 27 Mayls ve Kurucu Meclis'in Perde Arkası. Ankara: Töre-Devlet Yayınları.

Ulay, S. (1968). 27 Mayıs 1960 Harbiye Silah Başına. İstanbul: K Kitapç11ı.

Uraz, A. (1973). 12 Mart'a Doğru Devlet Organları ve Demokratik Kuruluşlar. İstanbul: Türkiye Ticaret Odaları, Sanayi Odaları ve Ticaret Borsalar Birliği Yayını.

Ünsal, A. (1980). Siyaset ve Anayasa Mahkemesi. Ankara: Ankara Üniversitesi Siyasal Bilgiler Fakültesi Yayınları.

Yasemin, D. (2017). İhtilalin Mantığı, Türkiye’nin 1960’lı Yılları (99 - 116). İstanbul: İletişim Yayınevi.

Yavuz, B. ve Bülbül, M. (2012). Çift Meclis Sistemi ve Türkiye, Gazi Üniversitesi Hukuk Fakültesi Dergisi. 16(1), 217-260. Doi: belirtilmemiş.

Yıldırım, S. (2015). Devlet Planlama Teşkilatına Sosyalist Planlama Açısından Bir Bakış Karamanoğlu Mehmet Bey Üniversitesi Sosyal ve Ekonomik Araştırmalar Dergisi. (17), 2332. Doi: belirtilmemiş.

Zürcher, E. (2017). Modernleşen Türkiye’nin Tarihi. İstanbul: İletişim Yayınları.

\section{ETİK ve BİLIMSEL İLKELER SORUMLULUK BEYANI}

$\mathrm{Bu}$ çalışmanın tüm hazırlanma süreçlerinde etik kurallara ve bilimsel atıf gösterme ilkelerine riayet edildiğini yazar(lar) beyan eder. Aksi bir durumun tespiti halinde Afyon Kocatepe Üniversitesi Sosyal Bilimler Dergisi'nin hiçbir sorumluluğu olmayıp, tüm sorumluluk makale yazarlarına aittir. 